\title{
14. CENOZOIC BIOSTRATIGRAPHY AND PALEOBIOGEOGRAPHY OF THE NORTH ATLANTIC
}

\author{
W. A. Berggren, Woods Hole Oceanographic Institute, Woods Hole, Massachusetts
}

\section{GENERAL}

The stratigraphic distribution of Cenozoic sediments recovered on Leg 12 is shown in Figure 1. Paleogene sediments were recovered at Sites 111, 112, 116, 117, 118 and 119. Neogene (including Pleistocene) sediments were recovered at all sites (Sites 111 through 119). The general planktonic and benthonic foraminiferal biostratigraphy at each site has been summarized in the text and figures accompanying the site reports. In this section we present a synthesis of the biostratigraphy and paleobiogeography of the North Atlantic based on Leg 12 results. For convenience in the following discussion the North Atlantic includes Sites 111 through 117; the Bay of Biscay includes Sites 118 and 119 .

\section{PLANKTONIC FORAMINIFERA}

\section{Paleogene}

Paleocene was recovered at Sites 117,118 , and 119. The oldest Paleocene recovered was at the bottom of Site 119 (core 40) in which an association of Globorotalia pseudobulloides, $G$. compressa, Globigerina triloculinoides, $G$. spiralis and Globorotalia angulata suggest an age of earliest Late Paleocene (top of Zone P2 or the base of Zone P3). Sediments of unequivocal Danian age were not cored on Leg 12.

Keeled globorotaliids (G. acuta-velascoensis group) occur in Upper Paleocene sediments at Sites 118 and 119, together with various acarininids. At Site 117 the Upper Paleocene contains small globigerinids referable to Globigerina triangularis and $G$. velascoensis, and acarininids (Figure 2).

Eocene sediments were recovered at Sites 111, 112, 117, 118 and 119. Lower Eocene keeled-globorotaliid faunas occur at Sites 111 (Orphan Knoll, Labrador Sea) and 118 (Bay of Biscay). At the latter site, in particular, rich and diverse faunas occur and include, among others Globorotalia subbotinae, $G$. marginodentata, $G$. aragonensis, $G$. formosa, $G$. formosa gracilis, Acarinina soldadoensis, A. soldadoensis angulosa, A. coalingensis, A. pentacamerata, Globigerina patagonica and Chiloguembelina wilcoxensis.

In the North Atlantic Middle Eocene sediments were recovered only at Sites 111 and 112 (Labrador Sea). Acarinina densa, Truncorotaloides collactea, Globigerina frontosa, G. patagonica, G. linaperta and Pseudohastigerina wilcoxensis characterize these levels in the Labrador Sea. Approximately equivalent levels in the Bay of Biscay (Site 118) contain similar acarininid faunas but include Globigerapsis index and Globorotalia pseudoscitula also.
Upper Eocene was cored only in the North Atlantic (Sites 112, 116, ?117). The dominant elements are Globigerina galavisi and Globigerinita unicava in the Labrador Sea, whereas at Rockall these forms are accompanied by Globigerina linaperta and Globigerapsis index. (Globigerapsis index appears to be a useful guide form in the Upper Eocene of high latitudes; it is common in the Upper Eocene of New Zealand, as well as in the Upper Eocene of Denmark and the North Sea.) Chiloguembelinids occur sporadically in the Upper Eocene of the North Atlantic and range into the lower part of the Upper Oligocene at several sites.

The Oligocene was cored in the North Atlantic (Sites $112,116,117)$ and the Bay of Biscay (Site 119). The dominant element at these sites is the group of globigerinitids (Globigerinita dissimilis and G. unicava primarily). Chiloguembelinids occur sporadically in the Lower Oligocene at Sites 116; Globigerina ampliapertura occurs in the lower part of the Lower Oligocene at Site 116, and Globorotalia munda in the upper part of the Lower Oligocene at Site 112. The association of globigerinitids, chiloguembelinids, $G$. munda and $G$. ampliapertura is useful in a biostratigraphic subdivision of the upper Paleogene of the North Atlantic (see Figure 3).

Although globigerinitids are common in the Upper Oligocene in the North Atlantic (Sites 112, 116 and 117), the occurrence of Globoquadrina baroemoenensis in the Upper Oligocene at Site 116 heralds the development of the genus as the dominant element in Lower Miocene sediments at this site and its usefulness in biostratigraphic subdivision. Globigerinitids continue as the dominant faunal element in the Upper Oligocene in the Bay of Biscay (Site 119). The absence of globoquadrinids and other characteristic Oligocene forms is attributed to selective solution (which is observed throughout most of the stratigraphic section cored at both Sites 118 and 119). Globorotalia opima-a stratigraphically important form-was found at Sites 117 and 119. An interesting fact is that although sediments of appropriate age were cored, the morphologically distinct and stratigraphically important Globigerina angulisuturalis was not found in any of the Upper Oligocene sediments on Leg 12.

A multiple planktonic foraminiferal zonation for the Paleogene of the North Atlantic based on assemblages at Sites $111,112,116$, and 117 is shown in Figure 2. This zonation scheme is based strictly on assemblages and is essentially biostratigraphic in nature. It is not formally defined here, but presented merely in order to demonstrate an ability to determine approximate positions within a standard time-stratigraphic scale. Approximate correlations of this high latitude zonation scheme with a composite zonation for low (tropical) latitudes is shown in Figure 4. 


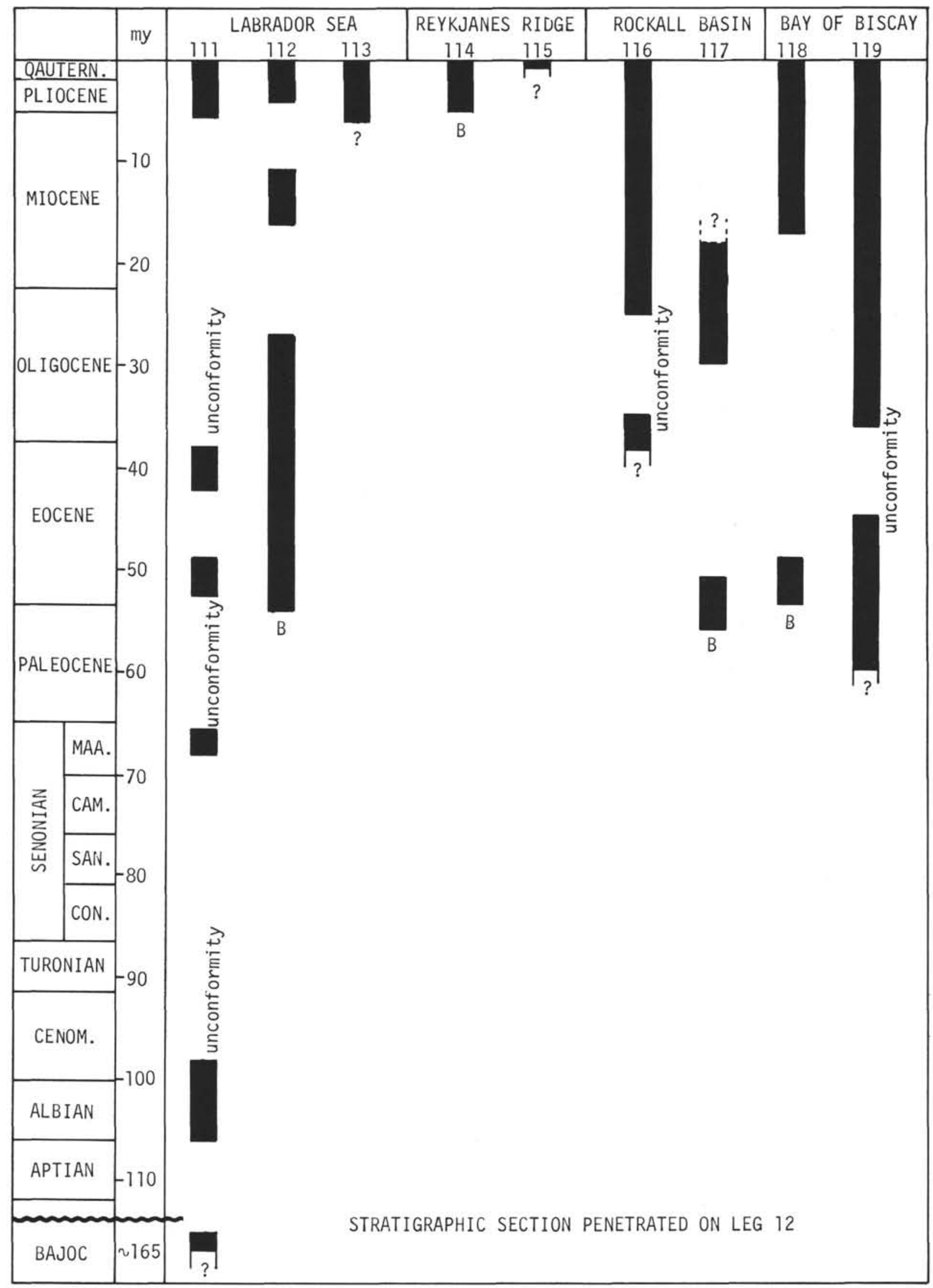

$\mathrm{B}=\mathrm{BASEMENT}$

Figure 1. Stratigraphic distribution of sediments cored on Leg 12. 


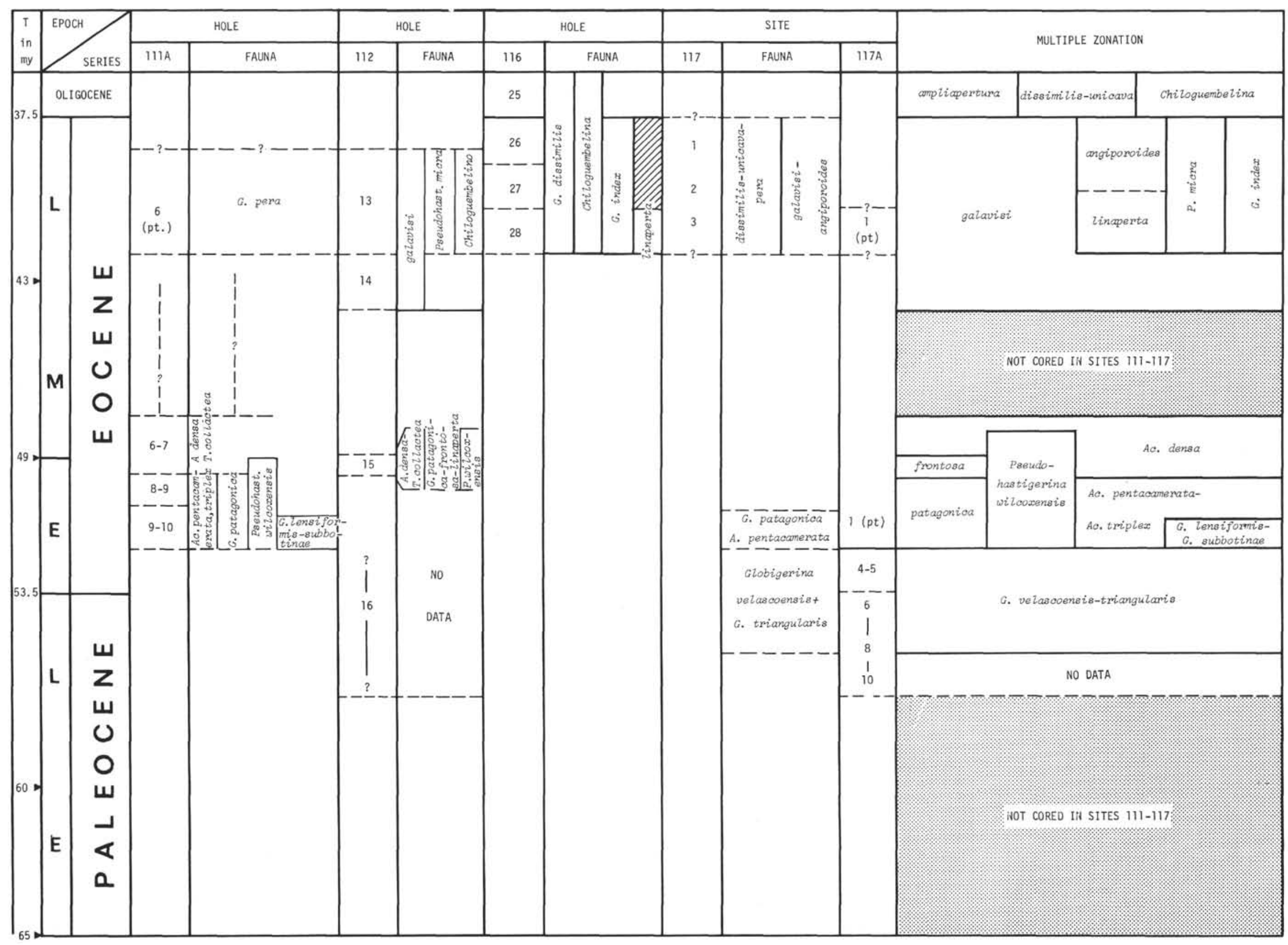


W. A. BERGGREN

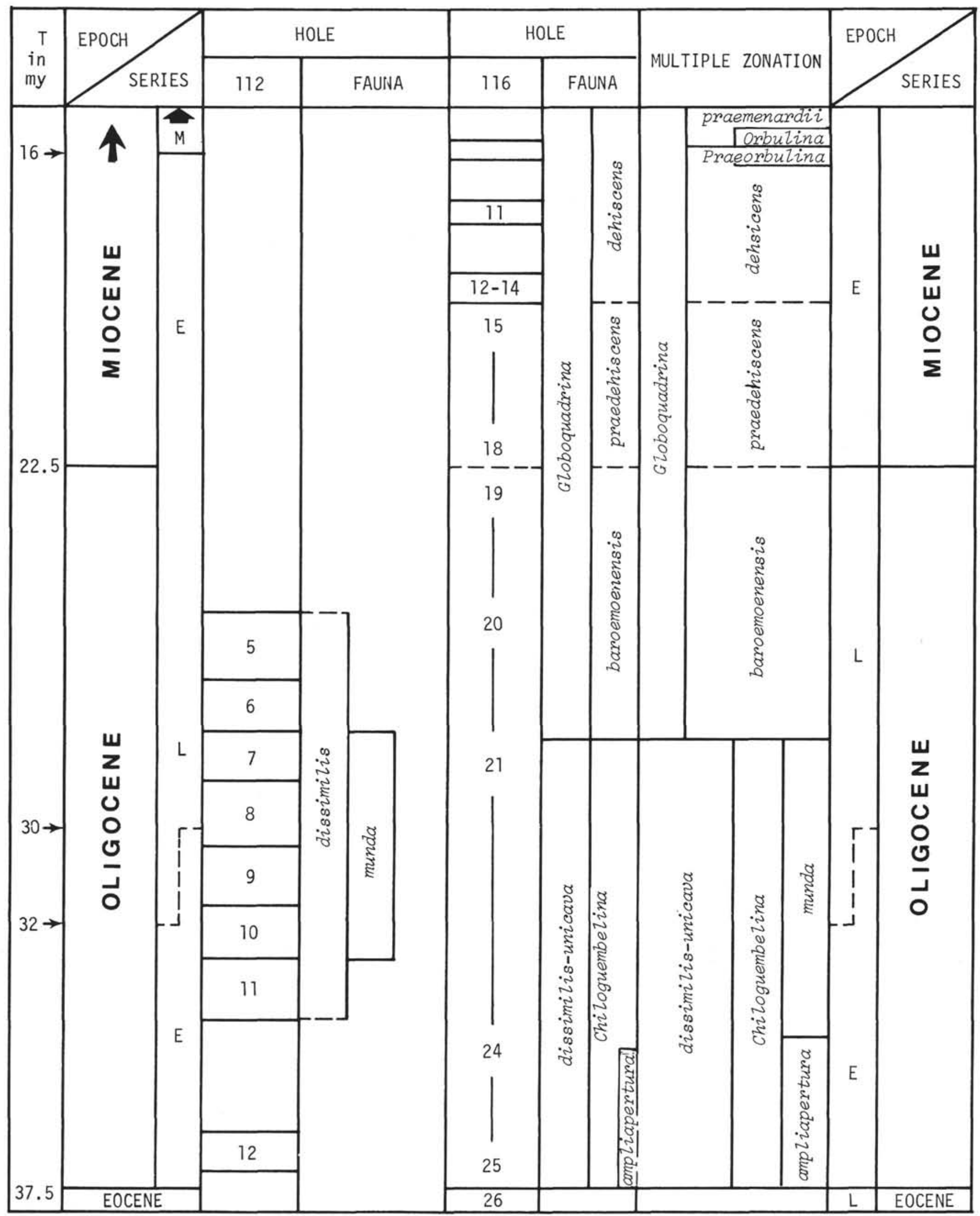

Figure 3. Oligocene-Lower Miocene planktonic foraminiferal biostratigraphy of the North Atlantic (Leg 12). 


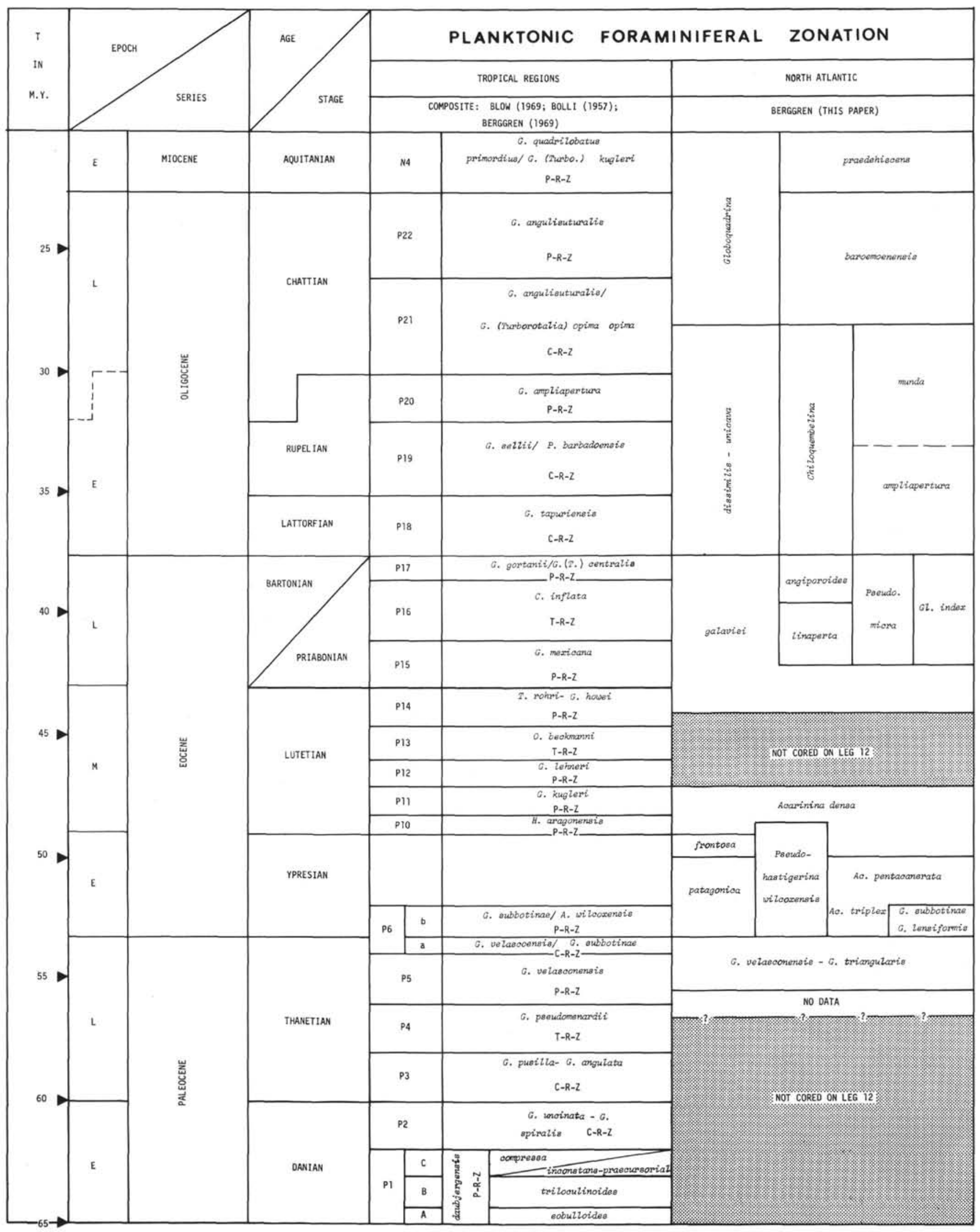

Figure 4. Correlation of Paleogene high and low latitude planktonic foraminiferal biostratigraphic zonation schemes. 


\section{Neogene}

Neogene sediments were cored at all sites on Leg 12 . (In this writer's concept, Neogene includes MiocenePleistocene, the Pleistocene including sediments to the present day.) Representative sections of the Miocene were cored in the North Atlantic (Site 116) and the Bay of Biscay (Sites 118 and 119). Questionable or extremely small amounts of Miocene sediments were recovered at Sites 111,113 and 114 .

The Lower Miocene at Site 116 is characterized by globoquadrinids ( $G$. praedehiscens to $G$. dehiscens) (Figure 3). Globigerinitids (G. dissimilis and $G$. unicava) occur commonly at both Sites 116 and 119 . Their presence at Site 119 is probably due to their greater resistivity to solution than other planktonic foraminifera. At Site 116 Sphaeroidinellopsis seminulina is particularly common in the upper part of the Lower Miocene (Burdigalian; approximately equivalent to Zone N7).

The Orbulina Datum, one of the most important datum levels in the Cenozoic, was cored at Site 116 (Core 116A10). In this core the evolutionary bioseries leading from Globigerinoides sicana to Praeorbulina glomerosa to Orbulina suturalis has been found (see Plate 4) and provides a valuable reference point in the stratigraphy of this site.

Representative Middle and Upper Miocene sediments were cored at Sites 116, 118 and 119. Questionable or minor amounts of Upper Miocene sediment were cored at Sites 111,112, 113 and 114. At the latter sites the planktonic foraminiferal faunas are extremely poor in the lower part of the stratigraphic section recovered and it is not possible to determine with any degree of certainty whether these levels are of late Miocene or early Pliocene age. One of the significant paleontologic discoveries of Leg 12 was the discovery that the Globorotalia miozea group can be used for Middle-Late Miocene biostratigraphic subdivision. This group appears to consist of Globorotalia praemenardii, $G$. moizea and G. conoidea. These forms succeed each other at Site 116. G. praemenardii is common in samples dated as equivalent to Zones N9-10. It is replaced above in a stratigraphic interval correlated approximately with Zones N12-13 (Serravallian) by G miozea. Globorotalia conoidea replaces $G$. miozea within a stratigraphic interval correlated approximately with the Serravallian/Tortonian boundary (that is, Middle/Upper Miocene).

A distinctive feature of the Middle Miocene at Sites 112 and 116 is the common occurrence of large, robust forms referred here to Globigerina praebulloides (Figure 5). Globigerina nepenthes was found in the Middle Miocene at Sites 112 and 116 as well. It occurs as a relatively common form in the Lower Pliocene at Site 111. At Site 118, Globorotalia miozea also occurs in the Middle Miocene in association with $G$. fohsi (Core 8). It occurs in association with Praeorbulina glomerosa circularis and Orbulina universa in Core 10. Thus the Middle Miocene planktonic foraminiferal faunas are rather similar at Sites 116 and 118 .

Several features characterize the Upper Miocene. In the North Atlantic, forms assigned to Globorotalia acostaensishumerosa dominate Upper Miocene assemblages at Site 116 (Figure 5). The development of Globigerina bulloides from G. praebulloides is observed at Site 116 in sediments correlated with Zone N16, and Globigerina apertura occurs in the Upper Miocene also at Sites 116 and 118. A distinctive form-Globigerina atlantica-appears for the first time at about the Middle/Upper Miocene boundary at Site 116. This form is dextrally coiled and present in small numbers in Upper Miocene sediments in the North Atlantic sites, but is sinistrally coiled and becomes the dominant element in the Pliocene at all North Atlantic sites. It is discussed in further detail below.

The Pliocene and Pleistocene were cored at all sites on Leg 12 with the exception of Site 117 (Figure 5). In a general way it would appear that the sequential appearance of Globorotalia puncticulata, G. crassaformis and G. inflata can be used for biostratigraphic subdivision of the Pliocene in the North Atlantic. Globorotalia puncticulata was not observed in pre-Pliocene levels and appears to be a useful marker for the Lower Pliocene. Globorotalia inflata appears at about the level coincident with the first glacially-rafted sediments, together with Globigerina pachyderma.

The dominant species in all North Atlantic Pliocene sites is Globigerina atlantica. In some instances this form occurs essentially alone to the exclusion of all planktonic species; more commonly it occurs associated with Globigerina bulloides, Globorotalia crassaformis, $G$. inflata, G. scitula, $G$. hirsuta and Orbulina universa. It is replaced gradually in the Late Pliocene by Globigerina pachyderma (which appears with the first glacially-rafted sediments). However, it disappears at the Pliocene/Pleistocene boundary (as determined by the extinction of Discoaster brouweri), and would appear to be a useful addition to the multiple criteria which now serve to determine this boundary in various parts of the world ocean. Although some forms assigned to G. atlantica bear a superficial morphologic resemblance to $G$. pachyderma, the two forms are quite distinct. Globigerina atlantica exhibits a wider range of morphologic variation, is consistently larger and has a thicker-walled test than $G$. pachyderma. Extreme variants of $G$. atlantica develop an extraumbilical aperture and bear a resemblance to Globorotalia humerosa. It is probable that $G$. atlantica has been described in publications on Mediterranean stratigraphy under different names. The significant fact here is that this is a morphologically and stratigraphically distinct form, which appears near the base of the Tortonian and ranges to the Pliocene/ Pleistocene boundary. It appears to change coiling direction (dextral to sinistral) at or near the Miocene/Pliocene boundary. Sinistrally coiled populations are indicative of a Pliocene age; the association of $G$. atlantica with other forms (such as, G. puncticulata, G. inflata, G. pachyderma) can be used in distinguishing approximate stratigraphic positions within the Pliocene (Figure 5).

The case of Orphan Knoll in the Labrador Sea (Site 111) is rather distinct in regards to late Neogene biostratigraphy. Latest Miocene and Pliocene (about .05 to 2.8 million years) are compressed into little over a meter of sediment at about 146 meters in a glauconitic ooze facies. A rich tropical-subtropical planktonic foraminiferal fauna has been recorded from this interval. This is overlain (with a transitional interval of about 15 centimeters) by glacially-rafted sands, silts and clays. The extinction of several stratigraphically important forms (Globorotalia multicamerata, Globoquadrina altispira, Sphaeroidinellopsis seminulina, S. subdehiscens) within this transitional interval and of various 


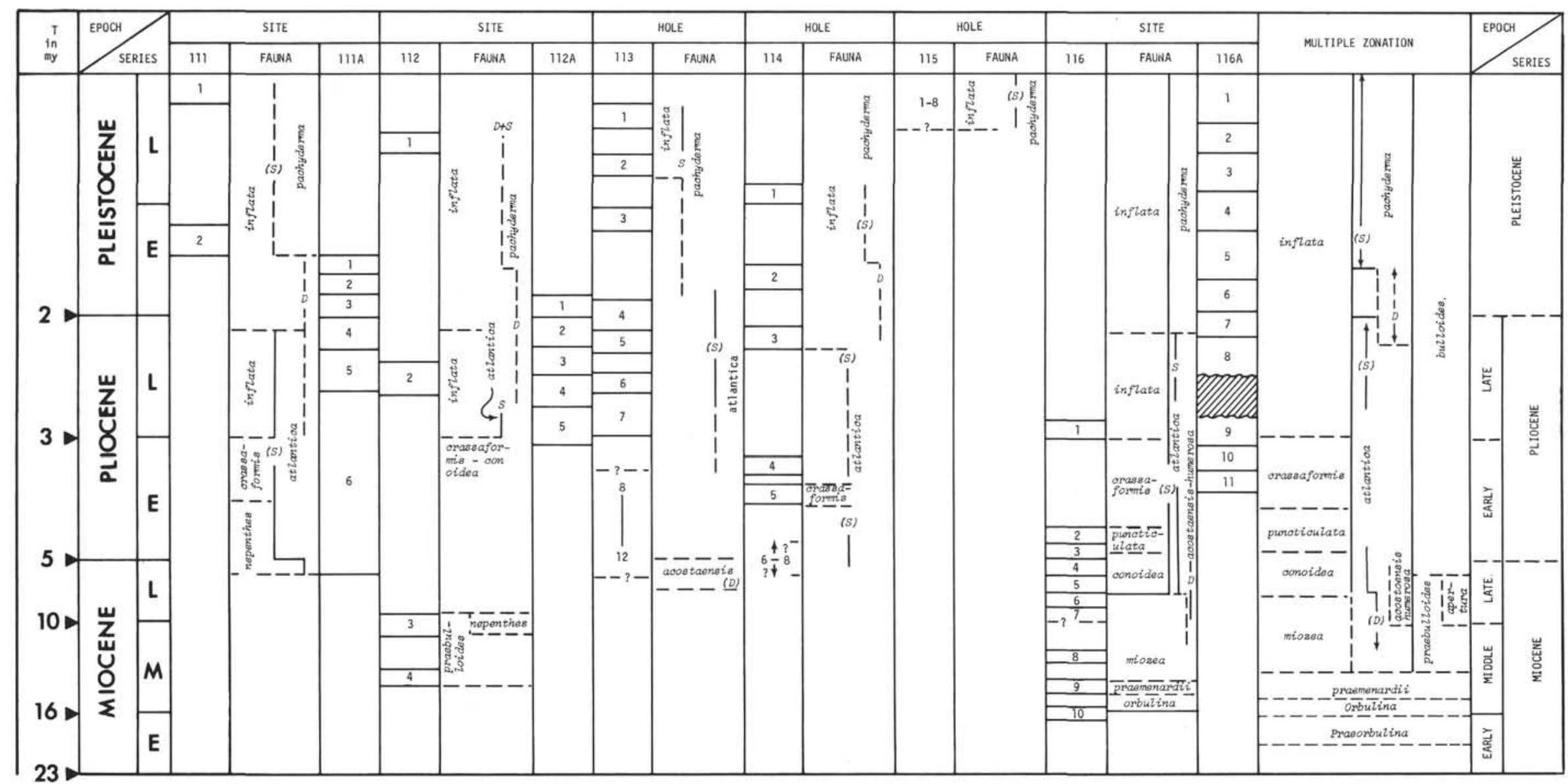

Figure 5. Neogene planktonic foraminiferal biostratigraphy of the North Atlantic (Leg 12). 
other species (Globoquadrina dehiscens, Globigerina nepenthes) at lower levels makes it possible to estimate the age of the various levels within this short interval based on known relationships with paleomagnetic stratigraphy elsewhere. The results, calculated in various ways, are internally consistent, and, an age of 3 million years has been estimated for the level of the first ice-rafted detritus.

There is a marked diminution in the planktonic foraminiferal fauna through the transitional interval, a response no doubt to the relatively rapid cooling of the sea at that time. Globigerina atlantica-a common form in the preglacial levels-becomes the dominant form in the glacial sediments and occurs together with Globigerina bulloides $G$. pachyderma and Globorotalia inflata.

Similar conditions were observed at site 112 near the central part of the Labrador Sea, about 360 kilometers northeast of Site 111. Although the stratigraphic sequence cored at Site 112 is not as extensive as at Site 111 (because of different rates of sedimentation), the pre-glacial/glacial boundary was cored and a marked decrease in fauna was observed across this boundary. In contrast to Site 111, the pre-glacial fauna at Site 112 contained fewer tropicalsubtropical species and a correspondingly greater proportion of temperate forms.

The Pleistocene was cored at all North Atlantic sites (with the exception of Site 117) and in the Bay of Biscay. In the North Atlantic Globigerina pachyderma, G. bulloides, and Globorotalia inflata are the dominant forms. A broad trend has been observed in Globigerina pachyderma: the species tends to be predominantly dextrally coiled in the Lower Pleistocene and sinistrally coiled in the Upper Pleistocene. This is probably a reflection of the intensification of glaciation in the Upper Pleistocene. Globorotalia truncatulinoides occurs as an accessory form at some sites in the North Atlantic $(111,115,116)$ and the Bay of Biscay $(118,119)$, but does not occur in quantities sufficient for stratigraphic utility.

A comparison of the biostratigraphically important Neogene planktonic foraminiferal assemblages encountered on Leg 12 is shown in Figure 5. A multiple zonation scheme based upon these assemblages is shown on the right side of this figure. As in the case of the multiple zonation proposed for the Paleogene of the North Atlantic above, this scheme is strictly biostratigraphic in nature and is, thus, not formally defined here. It is presented mainly as a guide to aiding stratigraphers in recognizing approximate levels within the standard time-stratigraphic scale at high latitudes in the North Atlantic. An approximate correlation of this multiple zonation scheme with a zonation based primarily upon tropical (low latitude) assemblages is shown in Figure 6.

\section{Globigerina atlantica spec. nov.}

Derivatio nominis: from its abundant occurrence in the North Atlantic sediments cored on Leg 12.

Diagnosis: A $4-5$ chambered globigerinid characterized by a relatively coarse granular surface, large apertural viarability and, during the Pilocene, by pronounced sinistral coiling.

Description: The adult test is average sized to large for the genus, coiled in a tight low-trochospire with $4-5$ chambers gradually increasing in size in the final whorl. The final chamber, usually the fifth, is often diminutive and caplike, extending in some instances down over the umbilicus. The test outline is broadly oval and the peripheral margin strongly lobulate. The intercameral sutures on the umbilical side are radial to slightly curved and distinctly incised. The primary aperture is a relatively low, narrow opening above the umbilicus but in some specimens it extends laterally towards, but not up to, the peripheral margin. An apertural lip is generally absent, the distal margin of the apertural region being developed as a thickened rim with spines being developed up to the edge; in rare instances a flanging lip is developed, particularly between the last two chambers. The calcareous wall is thick, and the test surface is densely covered with bluntly pointed spines giving the test a distinctly "granular" appearance. Within the umbilical region the spines are longer and sharper and somewhat less dense in their spacing.

The species is consistently sinistrally coiled in the Pliocene, whereas pre-Pliocene forms exhibit a preference for dextral coiling.

Remarks: This species is the dominant globigerinid and, indeed, the dominant planktonic foraminifer in most Pliocene samples in the North Atlantic encountered on Leg 12. In some instances it constitutes over $90 \%$ of the total planktonic foraminiferal fauna. It exhibits a preference for dextral coiling in the late Miocene but exhibits a pronounced sinistral coiling pattern in the Pliocene (over 95\%) up to its extinction at the Pliocene/ Pleistocene boundary.

This species is markedly similar to Globoquadrina dutertrei; it differs, however, in its consistently tighter coiling (and consequently narrower, smaller umbilicus), the greater variability of its aperture and in the "granular" test texture. This "granular" test texture is reminiscent of similar morphology developed in some forms of the genus Acarinina in the Paleogene. Indeed, the general test shape, outline and morphology of Globigerina atlantica is strongly similar to that developed in Acarinina mckannai and $A$. pentacamerata $(=A$. gravelli) during the late Paleocene and early Eocene. Globigerina atlantica also exhibits a general similarity to Globigerina pachyderma but can be distinguished by consistent size differences, in addition to discrete morphologic differences. G. pachyderma makes its initial appearance in all North Atlantic cores coincident with the first evidence of glaciation (ice-rafted detritus) and the two species are the dominant forms in upper Pliocene samples of the North Atlantic.

The present species may be related to the "Globorotalia" humerosa-Globoquadrina dutertrei group but at the present time it is not possible to discern definite kinship or phylogenetic trends in this highly complex and variable group. It would appear that this species has been recorded in the late Neogene of the Mediterranean region by Italian workers, but a more thorough comparison of actual specimens from this region must be made before this can be confirmed.

Globigerina atlantica has been recorded from sites $111,112,113,114,116$ and 118 of Leg 12.

Holotype: The holotype specimen (plate 2, fig. 8 ) is from sample 116A-8-CC (late Pliocene). 


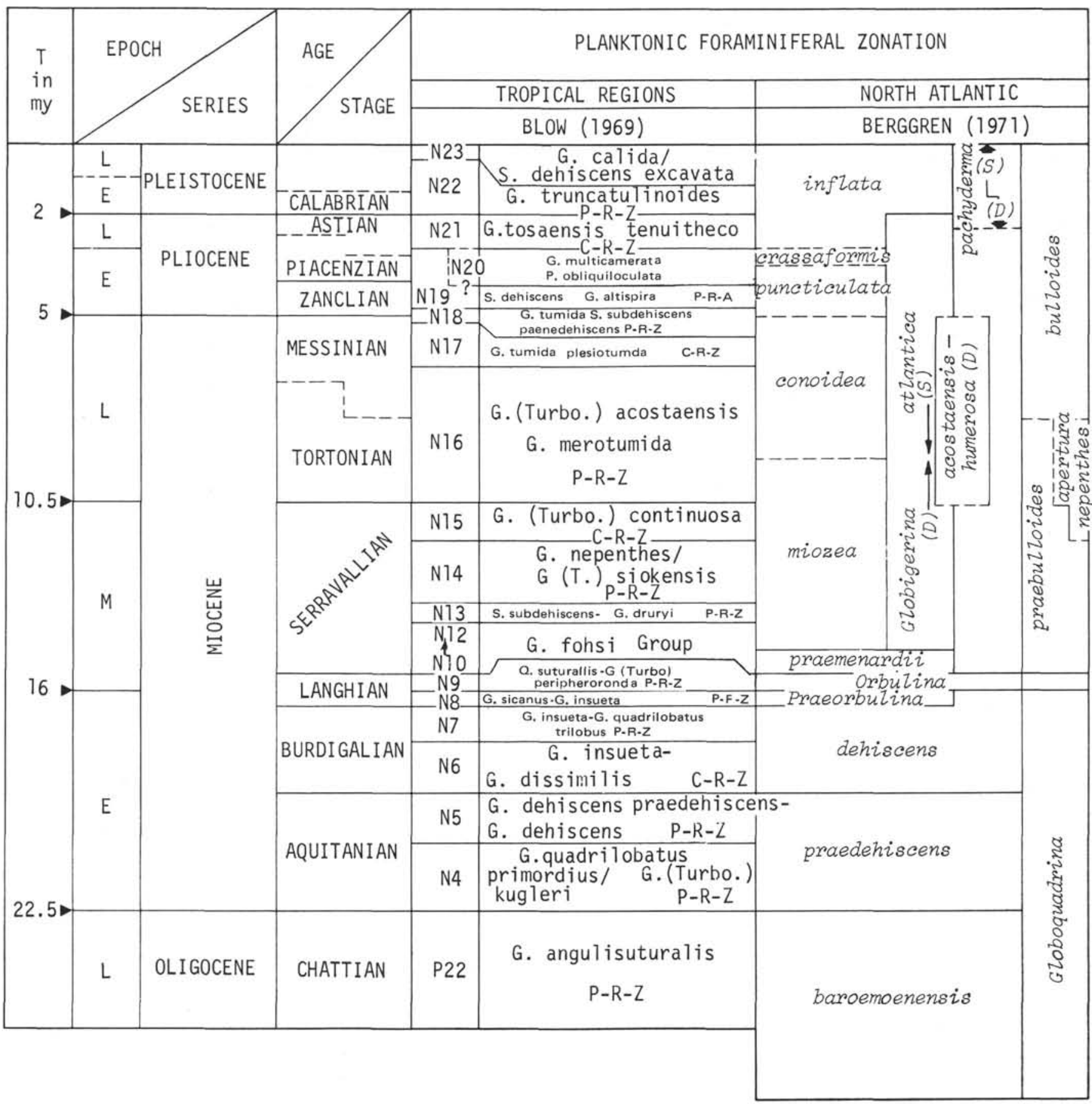

Figure 6. Correlation of Neogene high and low latitude planktonic foraminiferal biostratigraphic zonation schemes.

Stratigraphic Range: Globigerina atlantica has been observed from the late Miocene to late Pliocene (Zone N16-N21) in the North Atlantic. Sporadic and questionable occurrences in middle Miocene (Serravallian) samples-Zones N14-N15-have been observed.

\section{BENTHONIC FORAMINIFERA}

\section{General}

Benthonic foraminifera comprise one of the more interesting components of the fossil faunas encountered on
Leg 12. Because the sites drilled on Leg 12 ranged from 1050 to 4900 meters in water depth, and because some of them have undergone a history of sinking from relatively shallow depths to abyssal depths the benthonic foraminiferal faunas encountered on Leg 12 are of interest from the stratigraphic and paleobiogeographic point of view, and from the purely paleontologic-taxonomic point of view. In the section below we shall discuss the nature of the Cenozoic benthonic foraminiferal assemblages encountered on Leg 12, dividing the discussion into Paleogene and Neogene as above. 


\section{Paleogene}

Paleocene and Lower Eocene benthonic foraminiferal assemblages were recovered at Site 117. The Late Paleocene assemblages contain, among others, Anomalina acuta, Anomalinoides danica, Gavelinella neelyi, Cibicidoides propria, C. hercegovinensis, Osangularia pteromphalia, Lenticulina midwayensis, Vaginulina longiforma and Karreria fallax. This faunal assemblage exhibits strong similarity with those described from the Midway Formation of Texas, the Hornerstown-Vincentown sequence of New Jersey, the Paleocene of Denmark and Sweden and Poland, as well as equivalent levels in the Mediterranean region (North Africa and Italy). The assemblage is characteristic of continental shelf conditions in which the water depth probably did not exceed 200 meters.

In the Lower Eocene of Site 117, such forms as Anomalinoides grosserugosa, Cibicidoides sulzensis, Lenticulina decorata, L. alatolimbata appear-forms which are well-known from the Lower Eocene of western Europe.

Lower and Middle Eocene assemblages were encountered at Site 111. Among the benthonic foraminifera are: Anomalina acuta, A. praespissiformis, Anomalinoides grosserugosa, Osangularia pteromphalia, Cibicidoides hercegovinensis, C. acutimargo, Vaginulinopsis decorata, Gaudryina sp. cf. G. hiltermanni, Oridorsalis ecuadorensis, Nuttallides truempyi, Bulimina grata and various stilostomellids and pleurostomellids. This assemblage contains several elements characteristic of the Eocene of the Caribbean and European regions. In particular Nuttallides truempyi is a widespread form in deep-water facies in the Caribbean region. On Leg 12, it was found in the Eocene of the Labrador Sea (Sites 111 and 112) and the Bay of Biscay (Sites 118 and 119). Indeed, the association of Nuttallides truempyi and various stilostomellids and pleurostomellids (and a relatively rich planktonic foraminiferal fauna) indicate that Orphan Knoll lay at considerable depth by the Early Eocene (comparable to its present depth perhaps: 1800 meters).

Eocene benthonic foraminiferal faunas were also encountered at Sites 112 and 116. In the case of the former, a relatively diverse agglutinated fauna characterizes the ?Upper Paleocene-Lower, Middle and Upper Eocene interval. Forms referable to the following genera have been observed: Cyclammina, Glomospira, Ammodiscus, Bolivinopsis, Rhabdammina, Cribrostomoides and Haplophragmoides. In addition various calcareous forms occur sporadically: Osangularia pteromphalia, Oridorsalis ecuadorensis, Nuttallides truempyi, Cibicidoides sp. and various siphonodosariids and stilostomellids. The association indicates that Site 112 lay at bathyal depths in the Eocene.

The Upper Eocene at Site 116 is characterized by an abundance of Osangularis mexicana; also present are $\mathrm{Or}$ idorsalis ecuadorensis, Cibicidoides perlucida, and various cibicidids and siphonodosariids.

Eocene benthonic foraminiferal faunas in the Bay of Biscay (Sites 118 and 119) are characterized by a relatively high diversity. Among the forms recorded from the Lower-Middle Eocene are: Cibicidoides havanensis, $C$. trinitatensis, C. martinizensis, Oridorsalis ecuadorensis, Alabamina dissonata, Bulimina grata, Nuttallides truempyi, Pleurostomella naranjoensis, $P$. beirigi, Karreriella chapapotensis, Nodosarella mappa, N. subnodosa, Stilostomella verneuili, S. paucistriata, and Gaudryina sp. cf. G. hiltermanni. This assemblage shows a strong affinity with those described from the Caribbean-Antilles region, in particular, the Barbados section. The faunal association, together with the evidence of solution effects on the planktonic foraminiferal fauna, indicates that the Bay of Biscay abyssal plain lay at great depths in the Eocene, probably comparable to its present depth.

Representative Oligocene benthonic foraminiferal faunas were encountered at Sites 116 and 117 (North Atlantic), and Site 119 (Bay of Biscay).

In the Rockall area the characteristic Oligocene benthonic foraminifera include: i.al., Heterolepa mexicana, Cibicidoides perlucida, C. trincherasensis, Anomalinoides pompilioides, Anomalina alazanensis, Vulvulina jarvisi, Uvigerina mexicana and Siphonina tenuicarinata. The latter form is one of the dominant forms in Oligocene and Lower Miocene assemblages at Site 116 and at some levels is almost the only benthonic form present. This assemblage shows strong affinities with those recorded from the Oligocene of the Caribbean and Mediterranean regions and is indicative of middle-upper bathyal depths (about 300 to 600 meters).

The Oligocene at Site 119 (Bay of Biscay) is characterized by an abyssal assemblage including, among others, $\mathrm{Ci}$ bicidoides grimsdalei, C. martinizensis, Anomalina alazanensis, Anomalinoides semicribrata, Vulvulina jarvisi, Stilostomella abyssorum, Ellipsoglandulina multicostata, Stilostomella subspinosa, $S$. verneuili, Nodosarella subnodosa, $N$. mappa, and various pleurostomellids and cassidulinids. The fauna exhibits a marked affinity with those in the Oligocene of Barbados. The similar association here in what must have been abyssal depths during the Eocene-Oligocene and Early Miocene strongly supports the idea that the Barbados section was also deposited at similar depths.

\section{Neogene}

Representative Miocene benthonic foraminiferal assemblages were encountered at Site 116 (North Atlantic), and Sites 118 and 119 (Bay of Biscay).

The Lower Miocene assemblages at Site 116 are essentially the same as those which occur in the Oligocene. Along with the forms mentioned above, Planulina renzi and Anomalinoides pompilioides are characteristic of the Lower Miocene here. The Lower Miocene assemblages at Site 119 are essentially the same as those which occur in the Oligocene. Anomalinoides pompilioides, A. semicribrata, Cibicidoides trincherasensis, C. grimsdalei, Gyroidina complanata, various stilostomellids and cassidulinids are the most persistent forms.

In the Middle Miocene a change is seen in the benthonic foraminiferal faunas at Site 116 (North Atlantic), and Sites 118 and 119 (Bay of Biscay). Preliminary analysis of the material at hand suggests that the living bathyal-abyssal benthonic foraminiferal faunas developed in the Middle Miocene about 15 million years ago. Characteristic forms found in the North Atlantic sites (111 through 116) which range from the Middle Miocene to the present include:
Cibicidoides robertsoniana
Cibicidoides pseudoungeriana
Melonis pompilioides 
Melonis barleeanum

Gyroidina neosoldanii

Bulimina marginata

Eponides tener

Eponides umbonatus

Laticarinina halophora

Uvigerina peregrina

Uvigerina hollicki

Most of these forms occur in the Middle MiocenePleistocene of the Bay of Biscay sites (118, 119). An additional element not recorded in the North Atlantic sites is Epistominella exigua. The greater depth of water of the Bay of Biscay sites is reflected in their larger proportion of stilostomellids and pleurostomellids in comparison to the North Atlantic sites.

The references used in identifying the benthonic foraminiferal faunas on Leg 12 are listed at the conclusion of this chapter.

\section{ACKNOWLEDGMENTS}

The planktonic foraminifera in Plates 1-5 were photographed by Kenichi Harada, W.H.O.I., on a JEOLCO JSM-U3 scanning electron microscope. All benthonic foraminifera with the exception of those listed below were photographed by Francis Saffon, of the Paleontological Laboratory of the Societë National des Pëtroles Aquitaine (S.N.P.A.), Pau, France using a Cambridge Stereoscan. I should also like to thank Jane Aubert for her aid in preparing these specimens for study and in the assembly of the plates. Kenichi Harada, W.H.O.I., photographed the following benthonic specimens using a JEOLCO JSM-U3 scanning electron microscope: Plate 7, Figures 1-5; Plate 8, Figures 8-18; Plate 9, Figure 10; Plate 10; Plate 11, Figures 17-20.

This investigation was supported in part by Grant 6B16098 from the National Science Foundation. This is Woods Hole Contribution No. 2761.

\section{REFERENCES}

Bandy, O. L.. 1949. Eocene and Oligocene foraminifera from Little Stave Creek, Clark County, Alabama. Bull. Am. Paleontol. 32(131), 5, 27 pls.
Barker, R. W., 1960. Taxonomic notes on the species figures by H. B. Brady in his report on the foraminifera dredged by H.M.S. Challenger during the years 1873-1876. Soc. Econ. Paleontol. Mineral., Spec. Publ. (9), 238 pp., 115 pls.

Beckmann, J. P., 1953. Die Foraminiferen der Oceanic Formation (Eocaen-Oligocaen) von Barbados, Kl. Antillen. Ecologae Geol. Helv., 46, (2), 301, 30 pls.

Bermudez, P. J., 1949. Tertiary smaller foraminifera of the Dominican Republic. Cushman Lab. Foram. Res., Spec. Publ. (25), 322 pp., 26 pls.

Brotzen, F., 1948. The Swedish Paleocene and its foraminiferal fauna. Sver. Geol. Unders., Ser-C. (493), 140 pp., 19 pls.

Cushman, J. A., 1918-1931. The foraminifera of the Atlantic, U.S. Nat. Museum Bull. 104, pls. 1-8.

1951. Paleocene foraminifera of the Gulf Coastal Region of the United States and adjacent areas. U.S. Geol. Surv. Profess., Paper 232, 75 pp., 24 pls.

Cushman, J. A. and Stainforth, R. M., 1945. The foraminifera of the Cipero Marl Formation of Trinidad, British West Indies. Cushman Lab. Foram. Res., Spec. Publ. (14), 75 pp., 16 pls.

Dam, A. ten, 1944. Die stratigraphische Gliederung des niederländischen Paläozäns und Eozäns nach Foraminiferen. Meded. Geolog. Sticht., Ser C-V,(3), 142 pp., 6 pls.

Kaaschieter, J. P. H., 1961. Foraminifera of the Eocene of Belgium. Inst. Roy. Sci. Nat. Belgique, Mëm. (147), 271 pp., 16 pls.

Kiesel, Y., 1970. Die Foraminiferen fauna der paläozänen und eozänen Schichtfölge der Deutschen Demokratische Republik. Paläont. Abhandl. A, Bd. 4, H. 2, 163, pls. 1-27.

Nuttall, W. L. F., 1932. Lower Oligocene foraminifera from Mexico. J. Paleontology, 6 (1), 3, pls. 1-9.

Phleger, F. B., Parker, F. L. and Pierson, J. F., 1953. North Atlantic foraminifera. In Sediment Cores from the North Atlantic Ocean, Reports of the Swedish Deep-Sea Expedition, Volume 7, Gothenburg (Elanders Boktryckeri Akt.) (1), 122 pp., 12 pls.

Renz, H. H., 1948. Stratigraphy and fauna of the Agua Salada Group, State of Falcon Venezuela. Geol. Soc. Am., Mem. 32, 219 pp., 12 pls.

Staesche, K. and Hiltermann, H., 1940. Mikrofaunen aus dem Tertiär Nordwestdeutschlands. Abhandl. Reichsst. Bodenf., N. F., Berlin. H 201, 26 pp., 52 pls. 
PLATE 1

All specimens are from Site 111

Figures 1-4 Globigerina atlantica Berggren spec. nov. 12-111A. 6-2, 121.5-122.5 cm, 1: X45; 2-4: X71; Late Pliocene.

Figure 5 Globigerina atlantica Berggren spec. nov. 12-111A6-3, 29-30 cm. X74; Early Pliocene.

Figure 6 Globigerina atlantica Berggren spec. nov. 12-111A6-3, 39-40 cm. X74; Early Pliocene.

Figure $7 \quad$ Globigerina atlantica Berggren spec. nov. 12-111A6-3, 68.5-69.5 cm. X75; Early Pliocene.

Figure $8 \quad$ Globigerina nepenthes Todd. 12-111A-6-3, top. X73; Early Pliocene.

Figure 9 Globigerinoides conglobata (Brady). 12-111A-6-2, 121.5-122.5 cm. X44; Late Pliocene.

Figure $10 \quad$ Globorotalia miocenica Palmer. 12-111A-6-3, 29-30 $\mathrm{cm}$. X66; Early Pliocene.

Figures 11, 12 Globorotalia miocenica Palmer. 12-111A-6-3, 17-18 $\mathrm{cm}$. X77; Early Pliocene.

Figures 13, 14 Globorotalia margaritae Bolli. 12-111A-6-3, 7-8 cm. X73; Early Pliocene.

Figures 15-17 Globorotalia crassula Cushman and Stewart. 12-111 A-6-2, 121.5-122.5 cm. X63; Late Pliocene.

Figures 18, 19 Globorotalia tumida (Brady). 12-111A-6-3, 29-30 cm. $\times 54$; Early Pliocene. 


\section{PLATE 1}
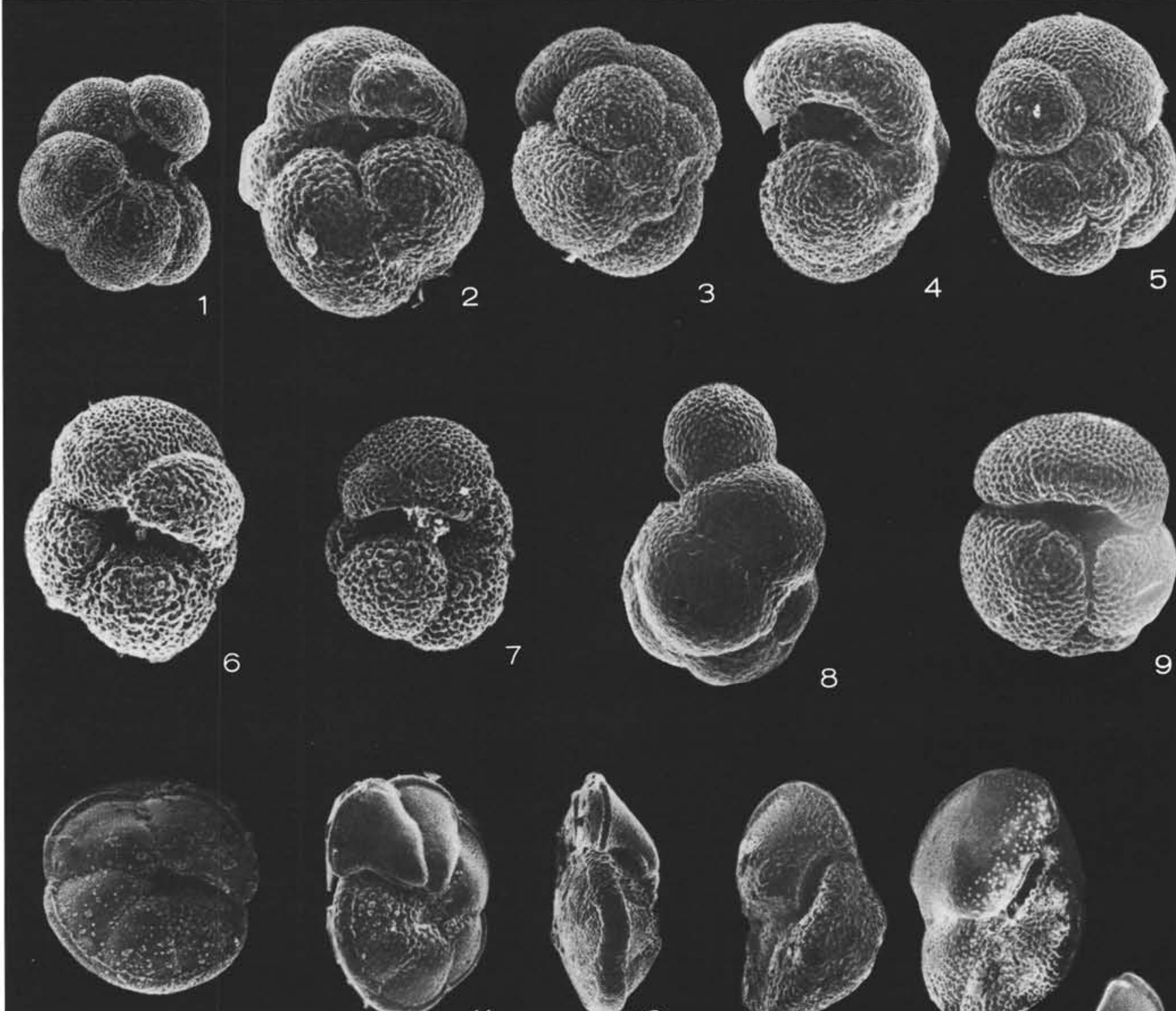

10
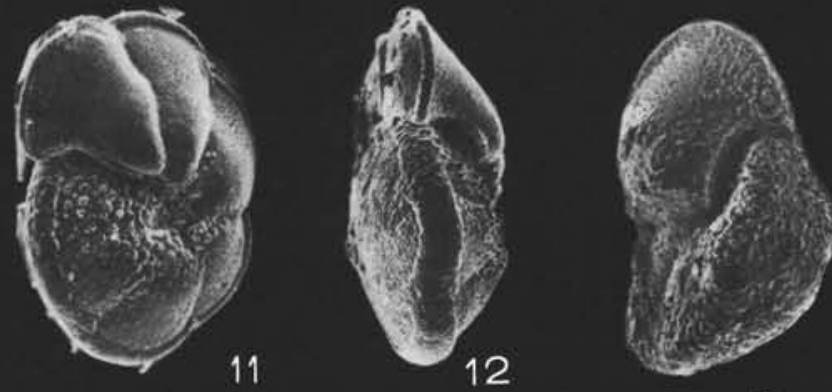

13
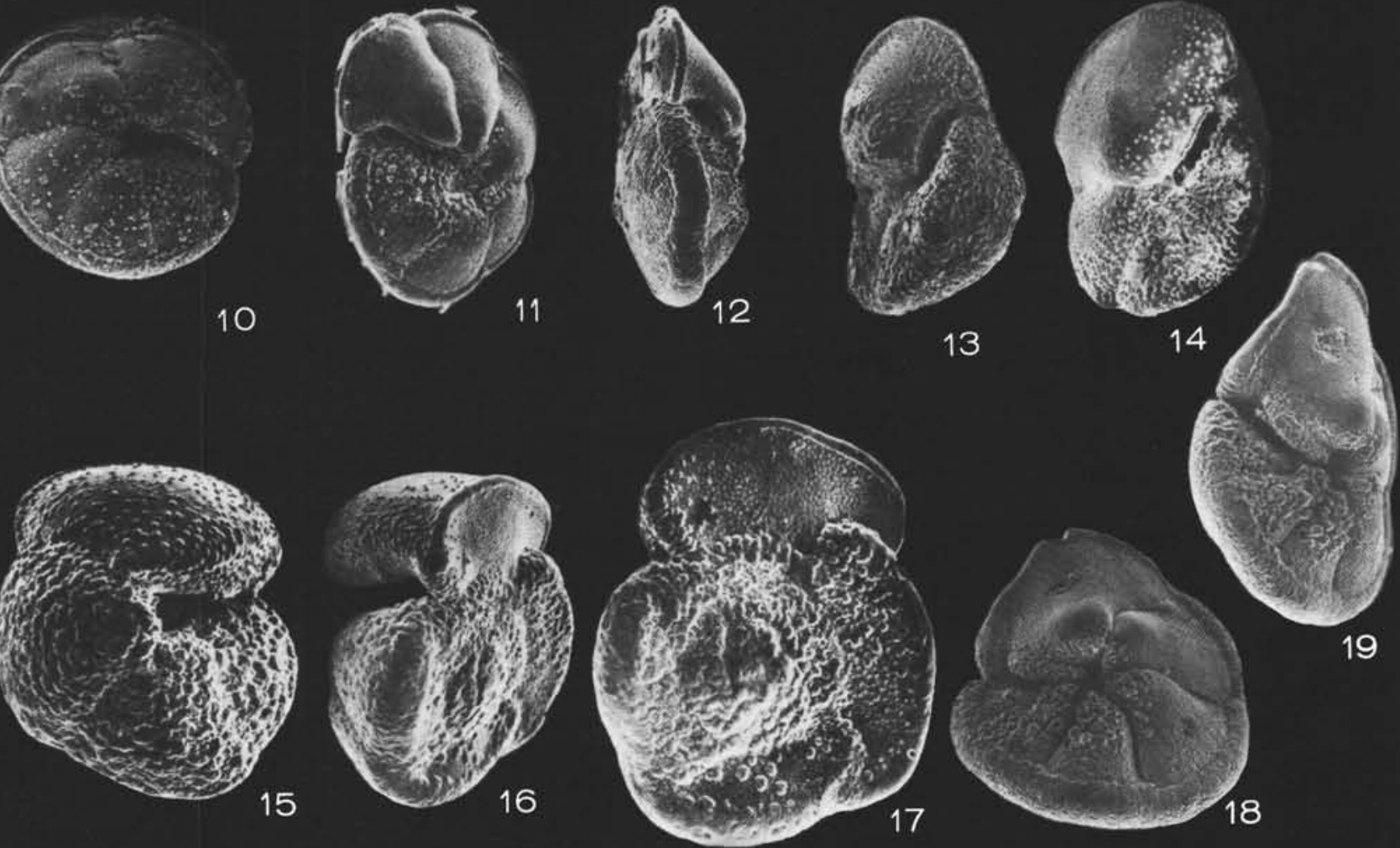


\section{PLATE 2}

Top row: all specimens from Site 113; all others from Site 116

Figures 1-4 Globigerina pachyderma (Ehrenberg). 12-113-2-3, $99-102 \mathrm{~cm}$. X95; Early Pleistocene; Figure 2 is same specimen as Figure 1, tilted to aperture.

Figures 5-8 Globigerina atlantica Berggren spec. nov. 12-116A-8, CC. 5 and $7: \times 50 ; 6: \times 60 ; 8$ holotype: $\times 72$; Late Pliocene.

Figures 9-12 Globorotalia humerosa Takayanagi and Saito. 12-116-7-0, bottom. 9 and $10: \times 110 ; 11: \times 78 ; 12$ : ×97; Middle-Late Miocene.

Figures 13, 14 Globorotalia acostaensis Blow. 12-116-4, CC. 13: X91; 14: X80; Late Pliocene.

Figures 15, 16 Globorotalia continuosa Blow. 12-116-7-1, 138-141 cm. X140; Middle-Late Miocene.

Figures 17, 18 Globigerina sp. 12-116-5-5, 140-143 cm. X72; Late Miocene. 


\section{PLATE 2}
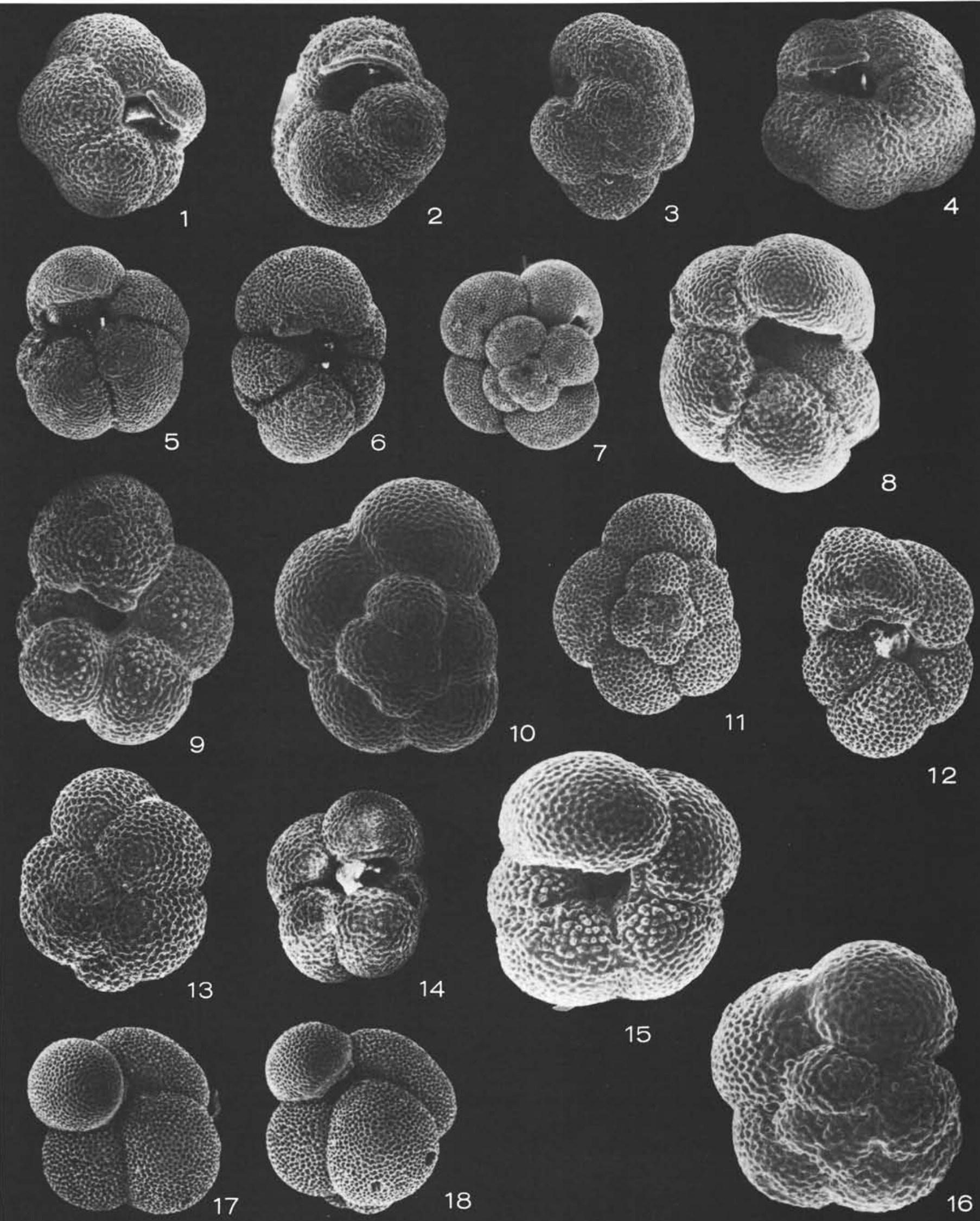

15

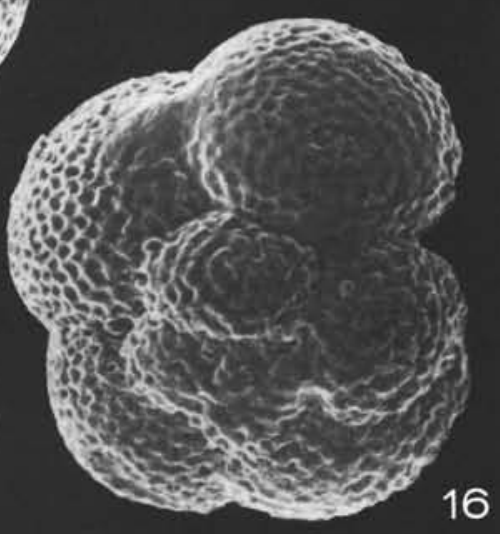


PLATE 3

All specimens from Site 116

Figures 1, 2 Globigerina nepenthes Todd. 12-116-7-1, 138-141 $\mathrm{cm}$. X 140; Middle-Late Miocene. Figure 2 is same specimen as Figure 1, tilted to show aperture.

Figure 3 Globigerina apertura Cushman. 12-116-5-0, bottom, X134; Late Miocene.

Figure 4 Globigerina zealandica Hornibrook. 12-116-9, CC. X100; Middle Miocene.

Figure $5 \quad$ Globigerina praebulloides Blow. 12-116-10, CC. X84; Early/Middle Miocene.

Figures 6-8 Globorotalia conoidea Walters. 12-116-2, CC. 6: X112; 7: X99; 8: X72; Early Pliocene.

Figures 9, 10 Globorotalia praemenardii Cushman and Stainforth. 12-116-9-2, 141-144 cm. 9: X83; 10: X52; Middle Miocene.

Figures 11, 12 Globorotalia birnageae Blow. 12-116-12-4, 124-127 $\mathrm{cm}$. X95; Early Miocene.

Figures 13, 14 Globoquadrina praedehiscens Blow. 12-116-16-4, 136-137 cm. X65; Early Miocene; same specimen rotated to show aperture.

Figure 15, 16 Globigerinita dissimilis (Cushman and Stainforth). 12-1 16-23-0, bottom. X90; Early Oligocene. 


\section{PLATE 3}

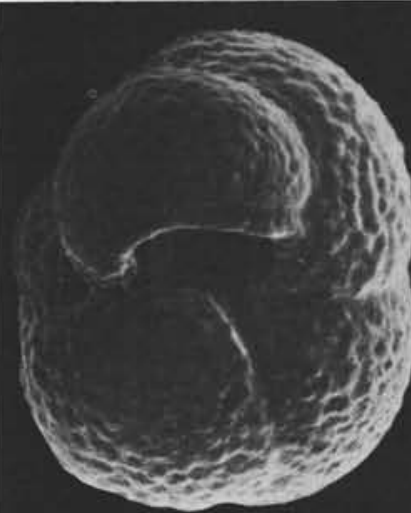

1

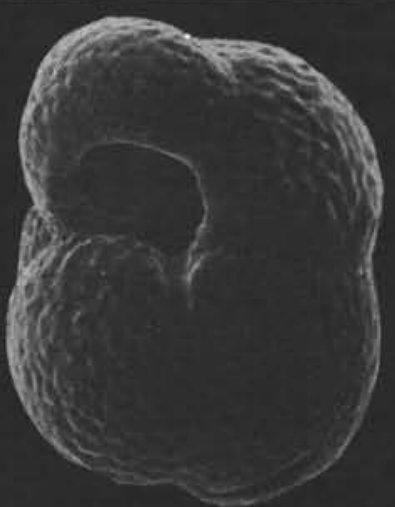

2

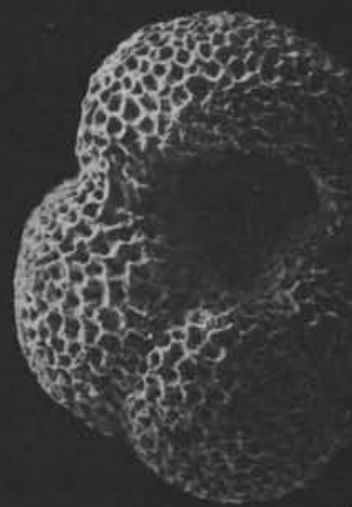

3

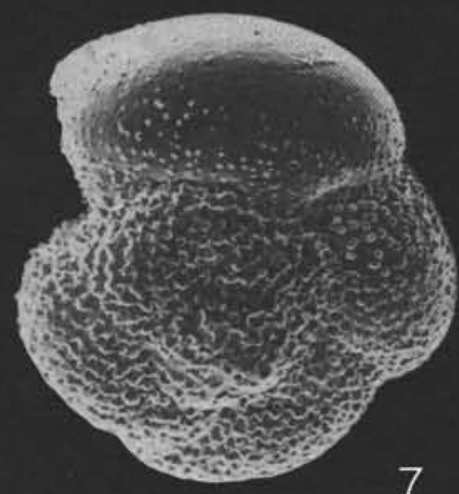

7

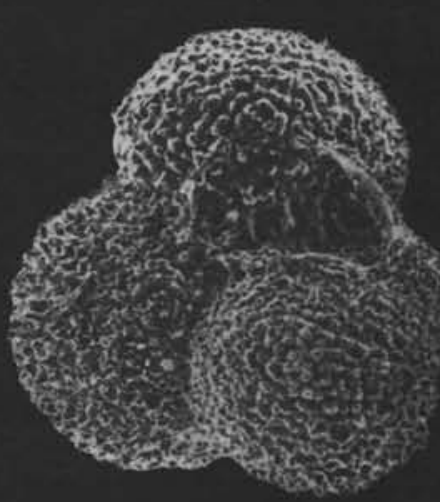

4

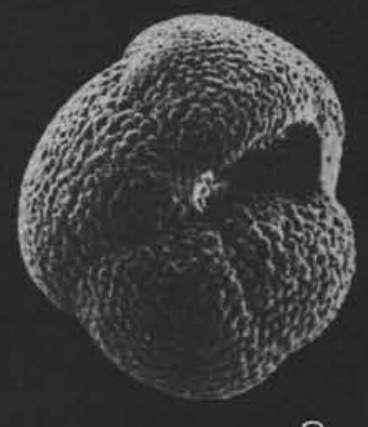

8
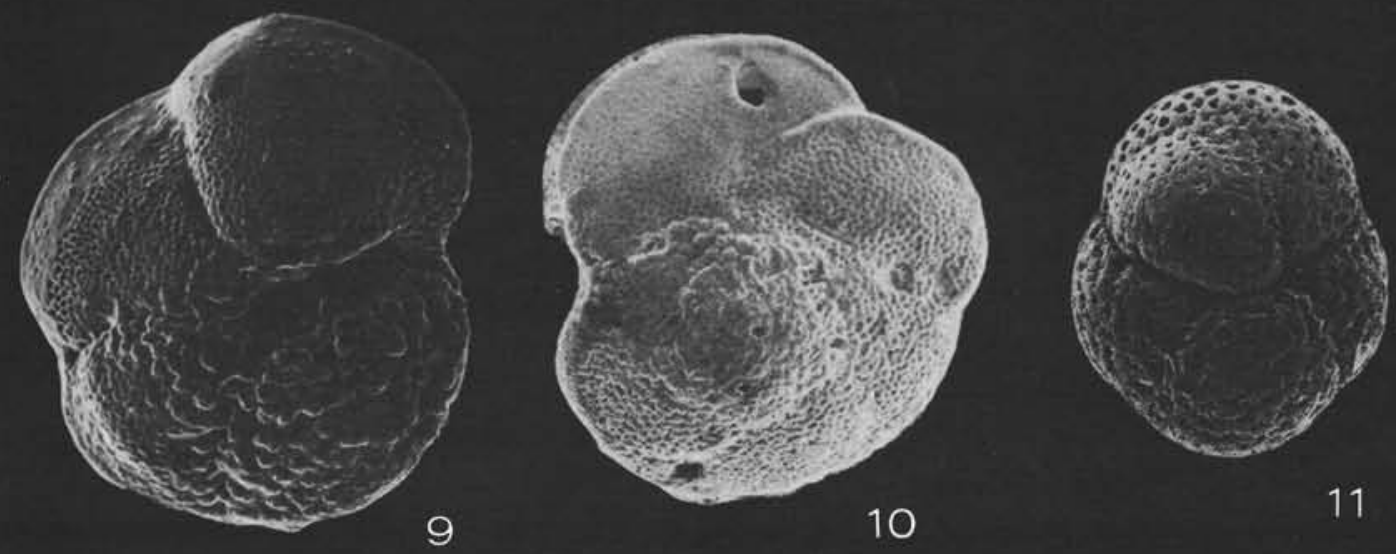

11
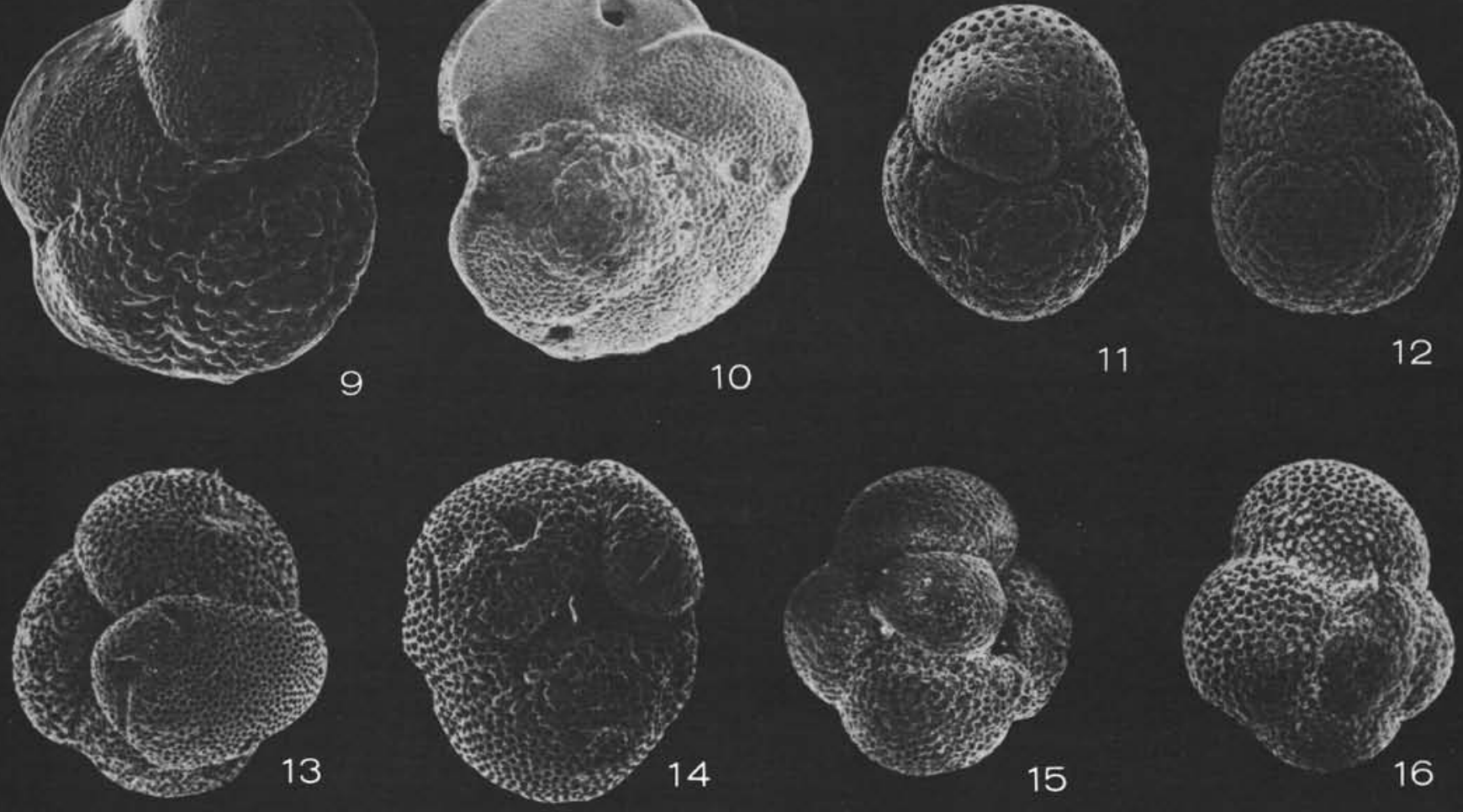


\section{PLATE 4}

All specimens from Site 116

Figure 1 Bilobate form generally referred to Biorbulina bilobata (d'Orbigny). 12-116-10-3, 62-63 cm. X98; Early/Middle Miocene.

Figure 2 Globigerinoides sicana (di Stefani). 12-116-10-5, $137-140 \mathrm{~cm}$. X95; Early Miocene.

Figure 3 Praeorbulina glomerosa curva Blow. 12-116-10-2, $63-65 \mathrm{~cm}$. X99; Early Miocene.

Figure $4 \quad$ Praeorbulina glomerosa glomerosa Blow. 12-116-10-2, $135-136 \mathrm{~cm}$. X118; Middle Miocene.

Figure 5 Praeorbulina glomerosa circularis Blow. 12-116-10-1, $62-65 \mathrm{~cm}$. X99; Middle Miocene. The sutural apertures are virtually indistinguishable along the sutural margins.

Figures 6, 7 Praeorbulina glomerosa circularis Blow. 12-116-10-1, 87-91 cm. 6: X106; 7: X143; Middle Miocene. Two views of a broken specimen to show interior detail. 


\section{PLATE 4}
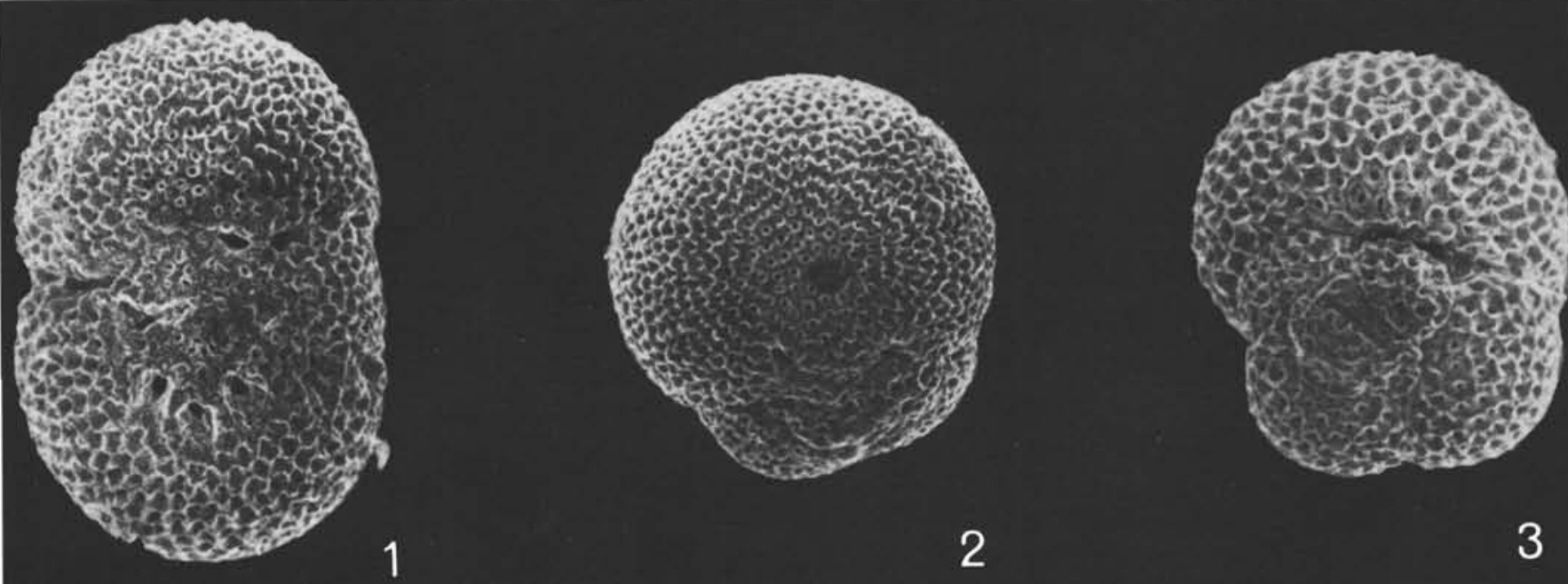

2
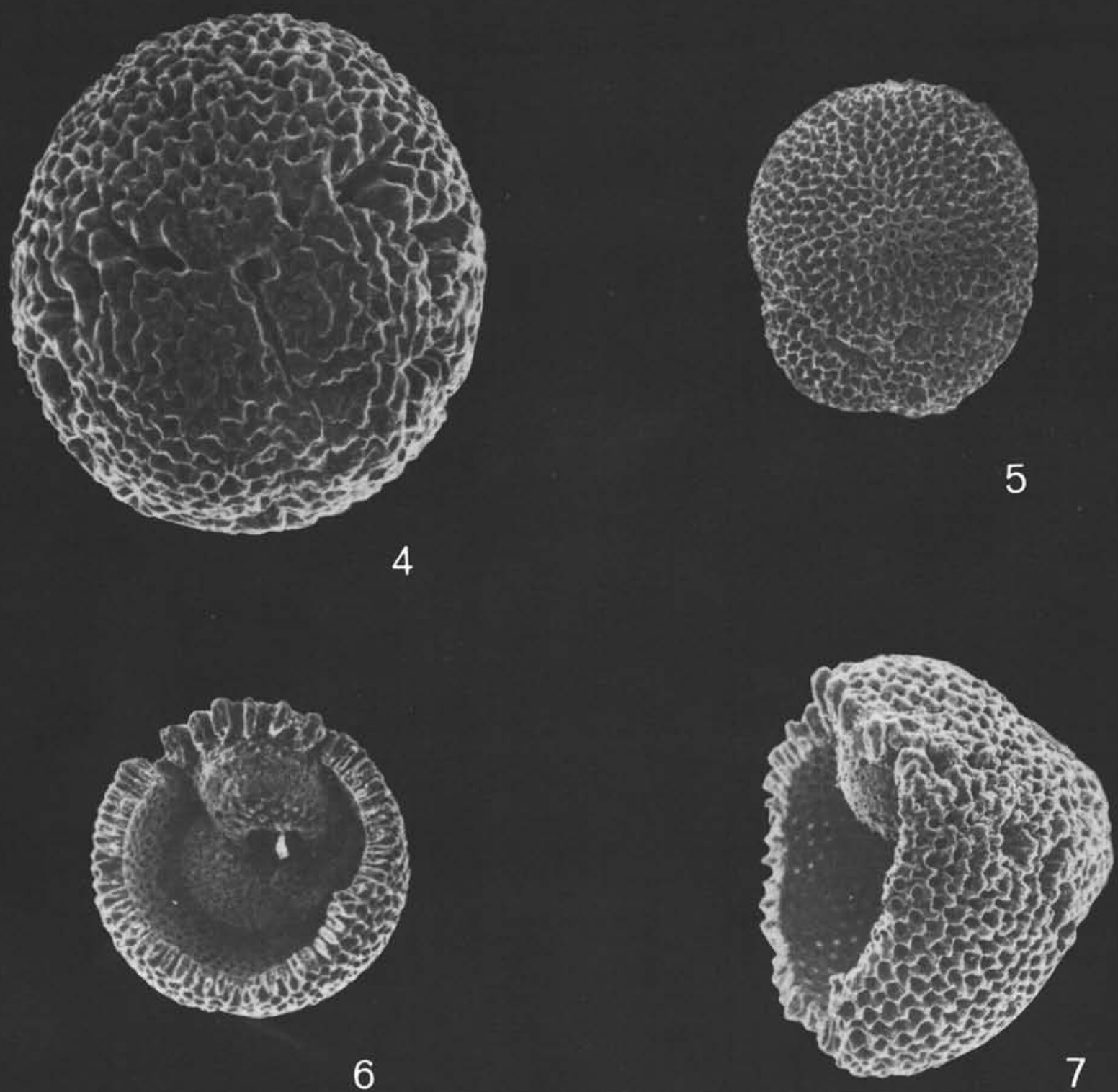

6 
PLATE 5

All specimens from Site 118

Figures 1, 2 Globorotalia subbotinae Morozova. 12-118-14, CC. X99; Early Eocene. Same specimen tilted to show apertural characters.

Figure 3 Globorotalia subbotinae Morozova. 12-118-15-1, 99-100 cm. X95; Early Eocene.

Figures 4-6 Globorotalia marginodentata Subbotina. 12-118-14, CC. X83; Early Eocene. 


\section{PLATE 5}

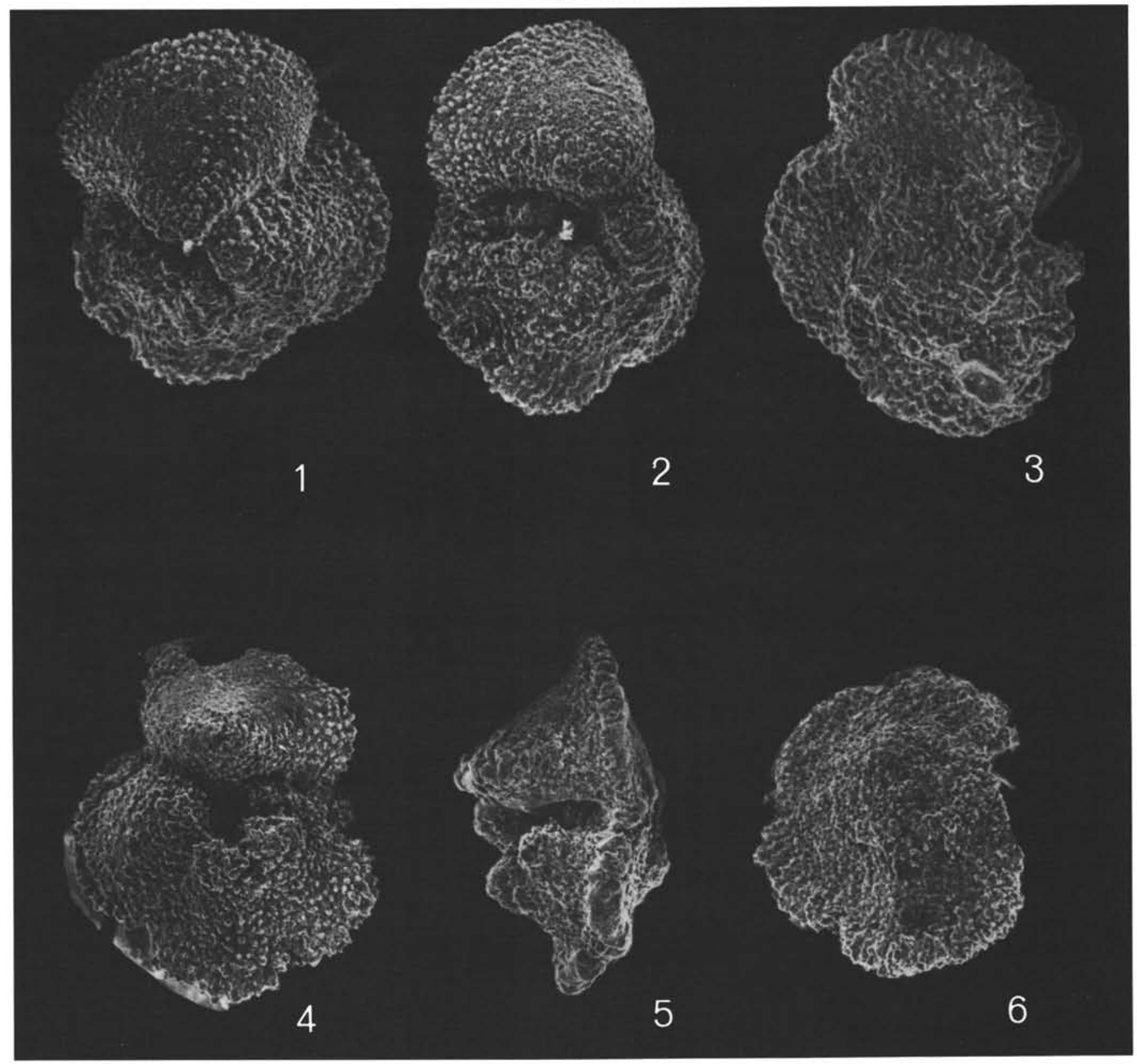


PLATE 6

All specimens are from Site 111

Figures 1-3 Neoconorbina sp. 12-111A-10-4, 148-150 cm. X120; Early Eocene.

Figure 4 Stilostomella bradyi (Cushman). 12-111A-2, CC. X160; Early Pleistocene.

Figure 5 Gavelinella limbata Olsson. 12-111A-8, CC. X168; Early Eocene.

Figure 6 Planulina ariminensis d'Orbigny. 12-111A-7-5, top. X70; Early Eocene.

Figures 7-9 Pulsiphonina prima (Plummer). 12-111A-7, CC. X121; Early Eocene.

Figures 10-11 Eponides tener (Brady). 12-111A-2-3, 137-138 cm. X120; Early Pleistocene.

Figures 12-14 Cibicidoides hercegovinensis (de Witt Puyt). 12-111A8, CC. 12 : X129; 13: X133; 14: X114; Early Eocene.

Figure 15 Bulimina notovata Finaly. 12-111A-2-4, 146-148 cm. X186; Early Pleistocene.

Figure 16 Cassidulina subglobosa Brady. 12-111A-5-5, 144-145 cm. X260; Late Pliocene.

Figures 17-19 Gyroidina soldanii d'Orbigny. 12-111A-2-5, 117-118 $\mathrm{cm}$. X128; Early Pleistocene.

Figure 20-22 Uvigerina hollicki Thalmann. 12-111A-2-4, 146-148 cm. 20 and 22: X80;21: X66; Early Pleistocene. 


\section{PLATE 6}
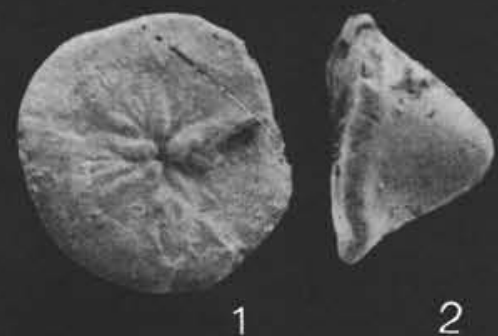

2

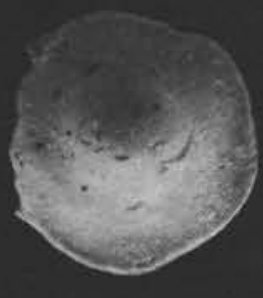

3

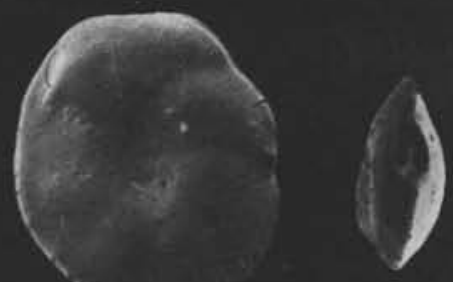

7

8

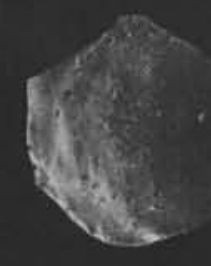

9

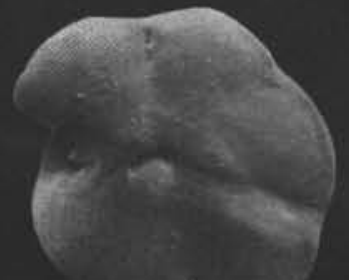

10

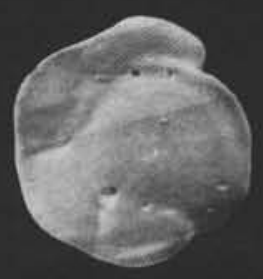

11

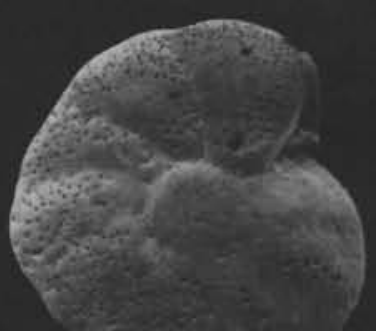

12
13

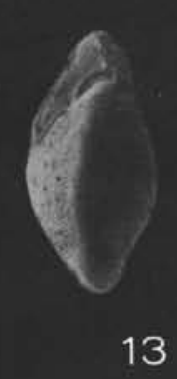

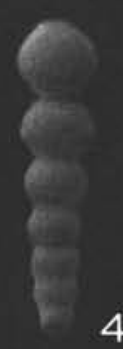

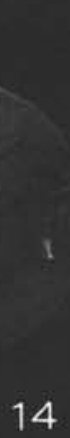

14
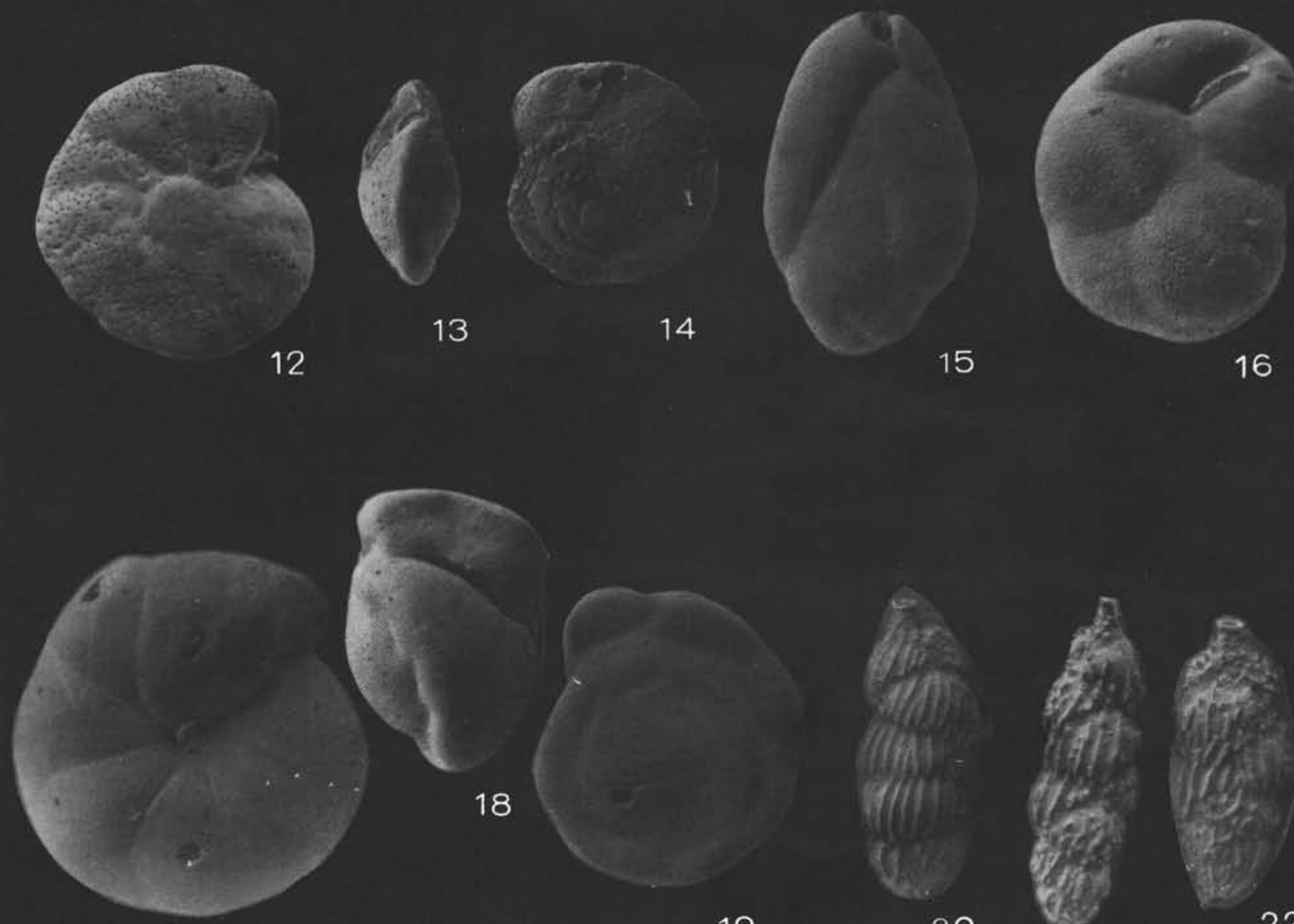

17
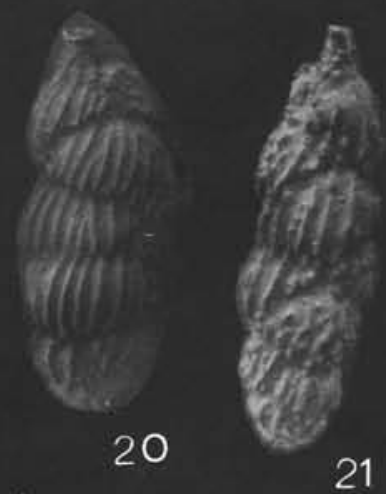
PLATE 7

Figures 1-5 are from Site 111;

Figures 6-11 are from Site 112

Figures 1-4 Cibicidoides pseudougeriana (Cushman). 12-111A$5-5,144-145 \mathrm{~cm}$. X40; Late Pliocene.

Figure 5 Benthonic foraminifer (?Cibicidoides pseudoungeriana) with chamber interiors filled with green (?glauconite) mineral; $12-111 \mathrm{~A}-6-2,126-127 \mathrm{~cm}$. X64; Late Pliocene.

The specimens figured below are from the same sample: $12-112-14, \mathrm{CC}$; Middle Eocene.

Figure 6

Figure 7

Figure 8

Figure 9

Figure 10

Figure 11
Glomospira sp.; $\times 125$.

Ammodiscus sp.; $\times 125$.

Rhabdammina sp.; $\times 60$.

Bolivinopsis sp.; $\times 114$.

Cribrostomoides sp.; $\times 125$.

Cyclammina sp.; $\times 60$. 

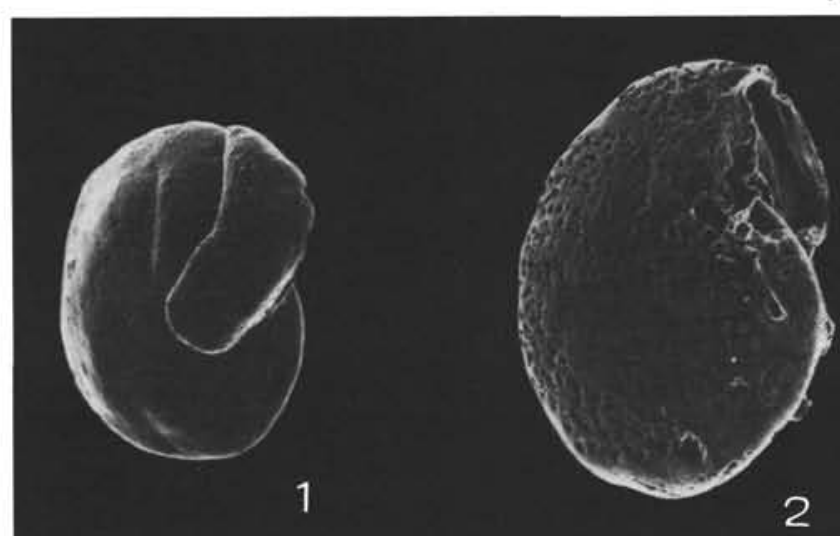

\section{PLATE 7}
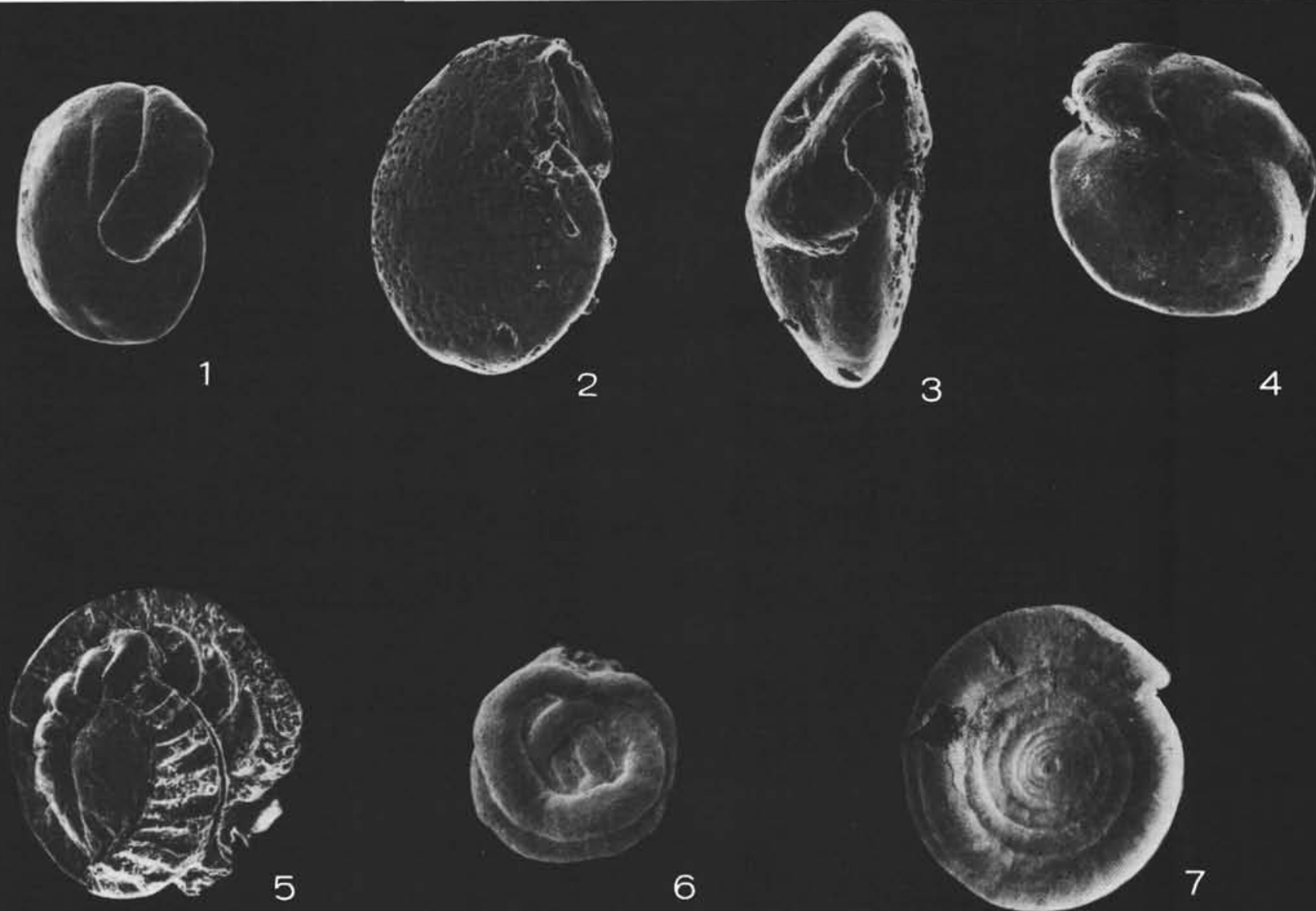

6
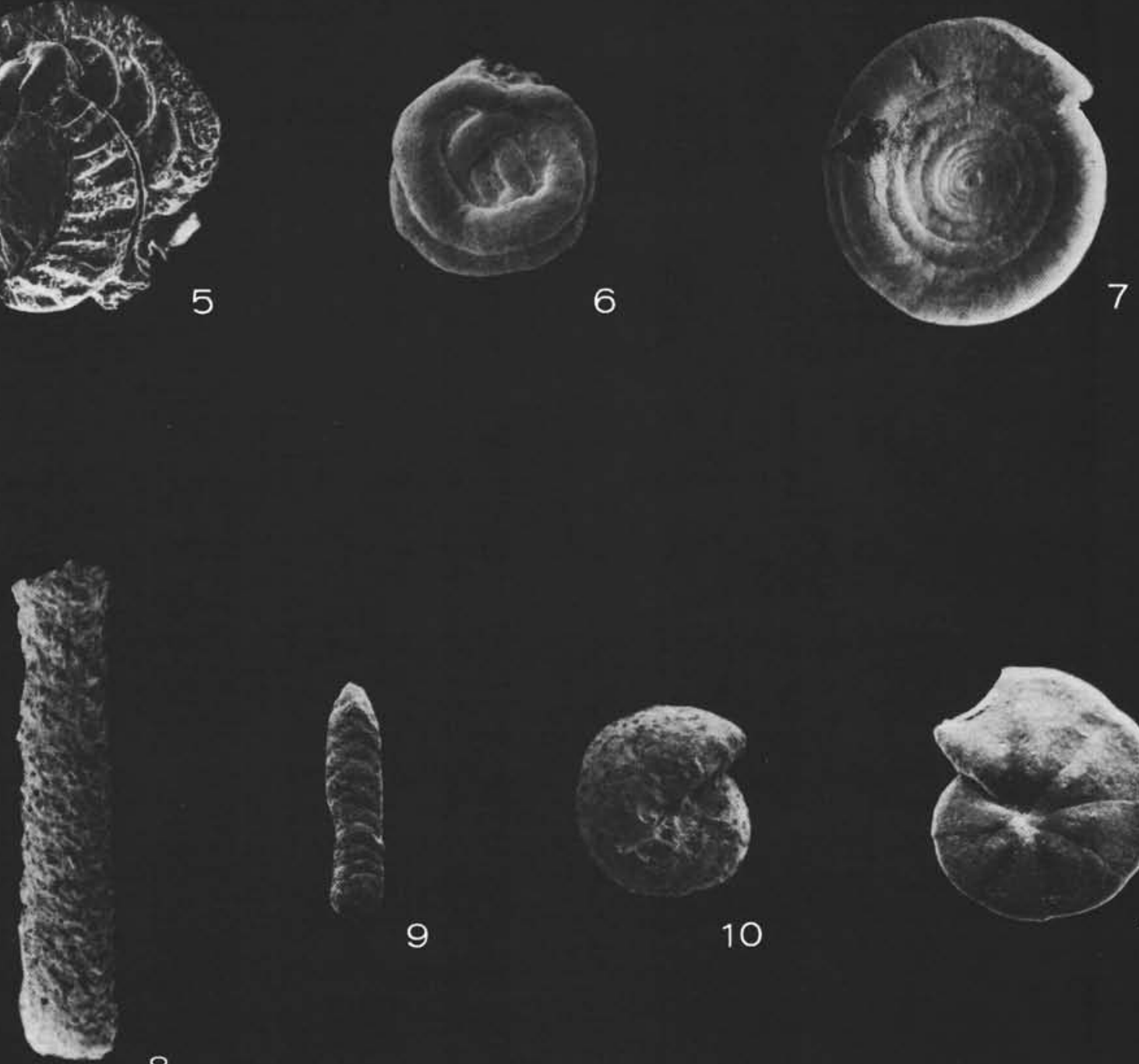

9

10

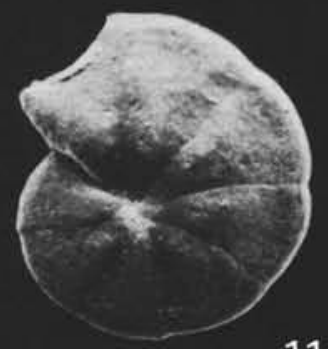




\section{PLATE 8}

All specimens are from Site 116

Figures 1, 2 Laticarinina halophora (Stache). 12-116-1, CC. 1: X138; 2: X44; Early Pliocene.

Figures 3, 4 Cibicidoides robertsoniana (Brady). 12-116-3, CC. X133; Early Pliocene.

Figure 5 Stilostomelia antillea (Cushman). 12-116-1-6, 143-145 cm. X137; Early Pliocene.

Figures 6,7 Uvigerina peregrina d'Orbigny. 12-116-1-4, 141-144 $\mathrm{cm}$. X65; Late Pliocene.

Figure $8 \quad$ Saracenaria italica de France. 12-116-6-3, 143-146 $\mathrm{cm}$. X24; Middle-Late Miocene.

Figure 9 Siphogenerina gaudryinoides (Lipparini). 12-116-3, CC. X36; Early Pliocene.

Figures 10,11 Uvigerina havanensis Cushman and Bermudez. 12-116-23-2, 124-127 cm. 10: X49; 11: X75; Early Oligocene.

Figures 12, 13 Dorothia sp. 12-116-6-2, 143-145 cm. 12: X18; 13: $\times 36$; Late Miocene. Two views of the same specimen, tilted slightly to show aperture.

Figures 14-16 Gyroidina girardana (Reuss). 12-116-25, CC. X62; Early Oligocene.

Figures 17, 18 Gyroidina jarvisi Cushman and Stainforth. 12-116-12-1, 144-147 cm. 17: X69; 18: X57; Early Miocene. 
PLATE 9

All specimens are from Site 116

Figure $1 \quad$ Nodosarella sp. 12-116-1-2, 146-149 cm. X86; Late Pliocene.

Figure 2 Dentalina advena (Cushman). 12-116-1-2, 146-149 cm. X82; Late Pliocene.

Figures 3, 4 Planulina bradii Tolmachoff. 12-116-1-1, 143-146 cm. X80; Late Pliocene.

Figures 5, 6 Eponides umbonatus (Reuss). 12-116-1-1, 143-145 $\mathrm{cm}$. X165; Late Pliocene.

Figures 7-9 Anomalinoides cicatricosa (Schwager). 12-116-1-1, 143-145 cm. X85, Late Pliocene.

Figures 10-12 Cibicidoides kullenbergi (Parker). 12-116-1, CC; $\times 130$. Late Pliocene.

Figure 13 Anomalinoides globulosa (Chapman and Parr). 12-116-5-0, bottom. X37; Late Miocene.

Figure $14 \quad$ Eggerella bradyi (Cushman). 12-116-3, CC. X130; Early Pliocene.

Figure 15 Sphaeroidina bulloides d'Orbigny. 12-116-1, CC. X130; Late Pliocene.

Figure 16 Uvigerina auberiana d'Orbigny. 12-116-2-1, 145-147 cm. X130; Early Pliocene.

Figures 17, 18 Martinotiella bradyana (Cushman). 12-116-3, CC. 17: $\times 130 ; 18$ : $\times 605$; Early Pliocene. Detail of aperture is shown in Figure 18. 


\section{PLATE 9}

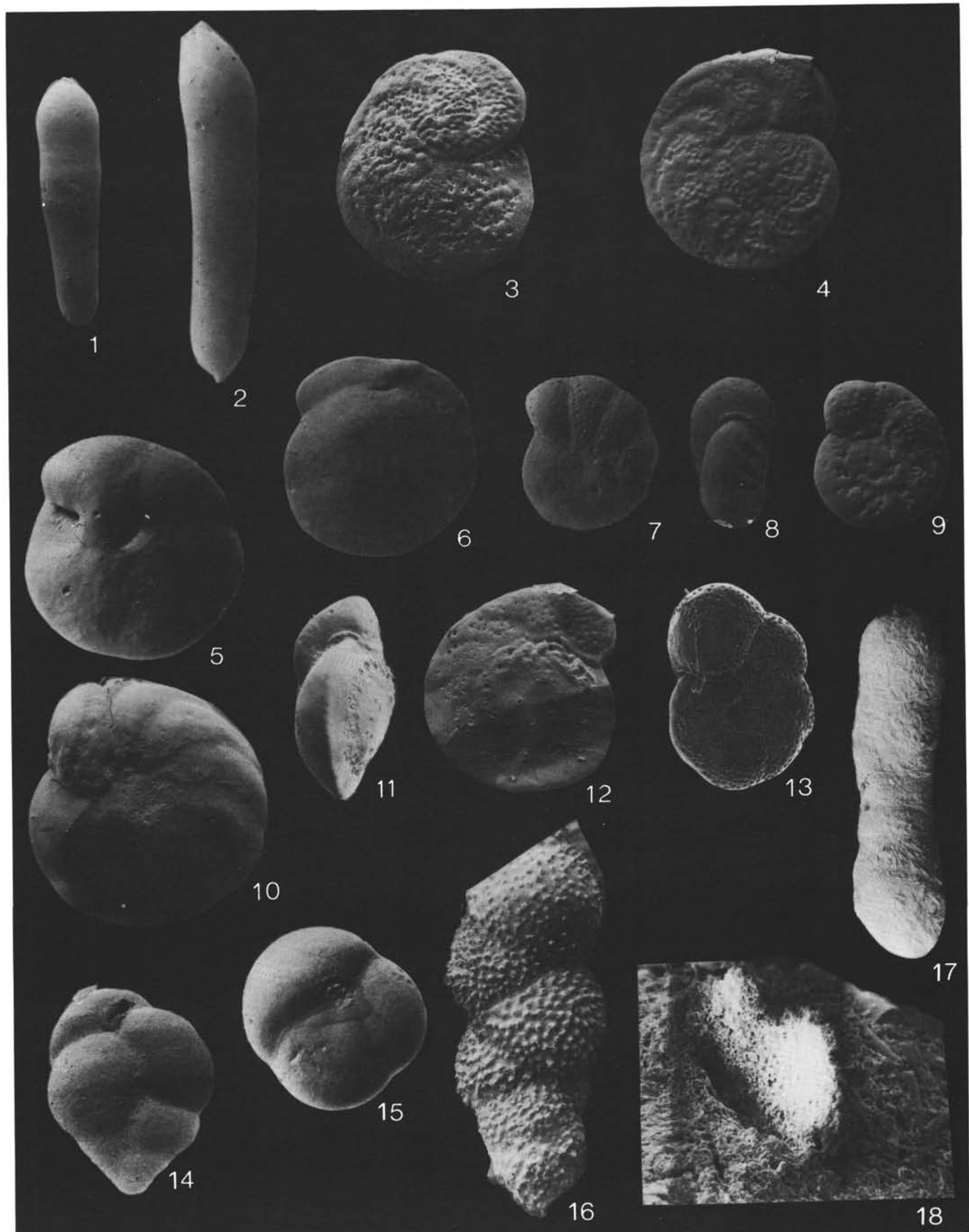




\section{PLATE 10}

All specimens are from Site 116

Figure 1 Cibicidoides trincherasensis (Bermudez). 12-116-16, CC. X35; Early Miocene.

Figures 2-4 Heterolepa mexicana (Nuttall), 12-116-22, CC. 2 and 4: $\times 50 ; 3: \times 60$; Early-Late Oligocene.

Figures 5, $6 \quad$ Planulina subtenuissima (Nuttall). 12-116-10-1, 87-91 cm. 5: $\times 40 ; 6: \times 53$; Middle Miocene.

Figures 7, 8 Planulina renzi Cushman and Stainforth. 12-116-23-2, $124-127 \mathrm{~cm}$. X60; Early Oligocene.

Figures 9-11 Planulina wuellerstorfi (Schwager). 12-116-8-2, 142-145 cm. 9: X55; 10: X68; 11: X77; Middle Miocene.

Figures 12, 13 Siphonina tenuicarinata Cushman. 12-116-10, CC. 12: X71; 13: X30; Early Miocene.

Figures 14-17 Gyroidina complanata Cushman and Stainforth. 12-116-10, CC. $14: \times 31 ; 15: \times 72 ; 16: \times 37 ; 17: \times 54$; Early Miocene. 


\section{PLATE 10}

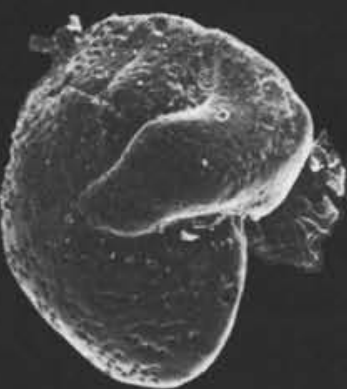

1

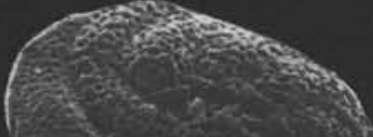

5

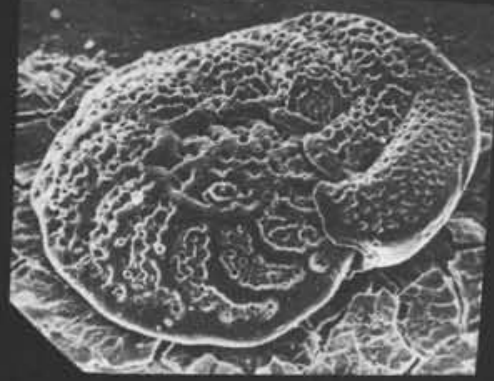

6

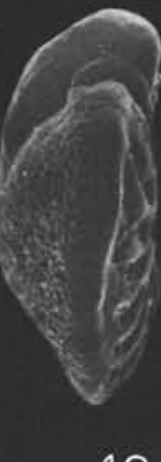

10

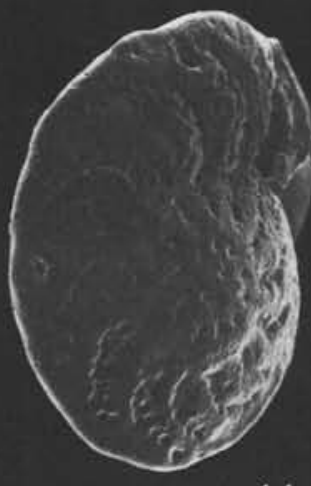

11
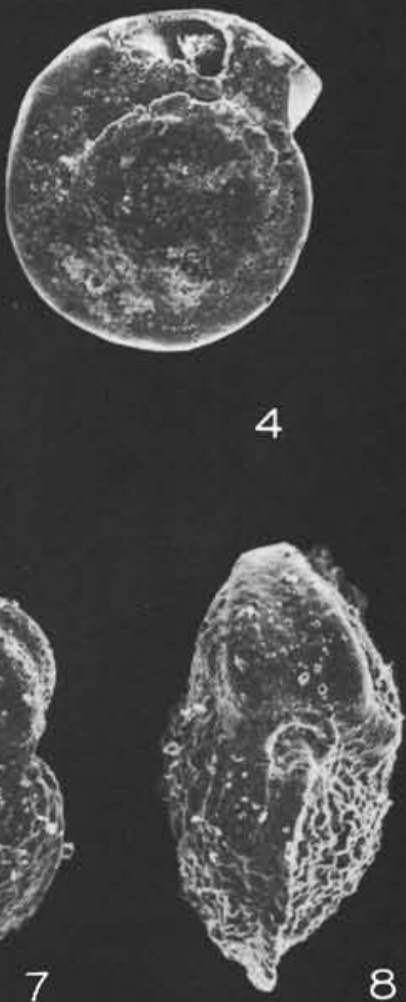
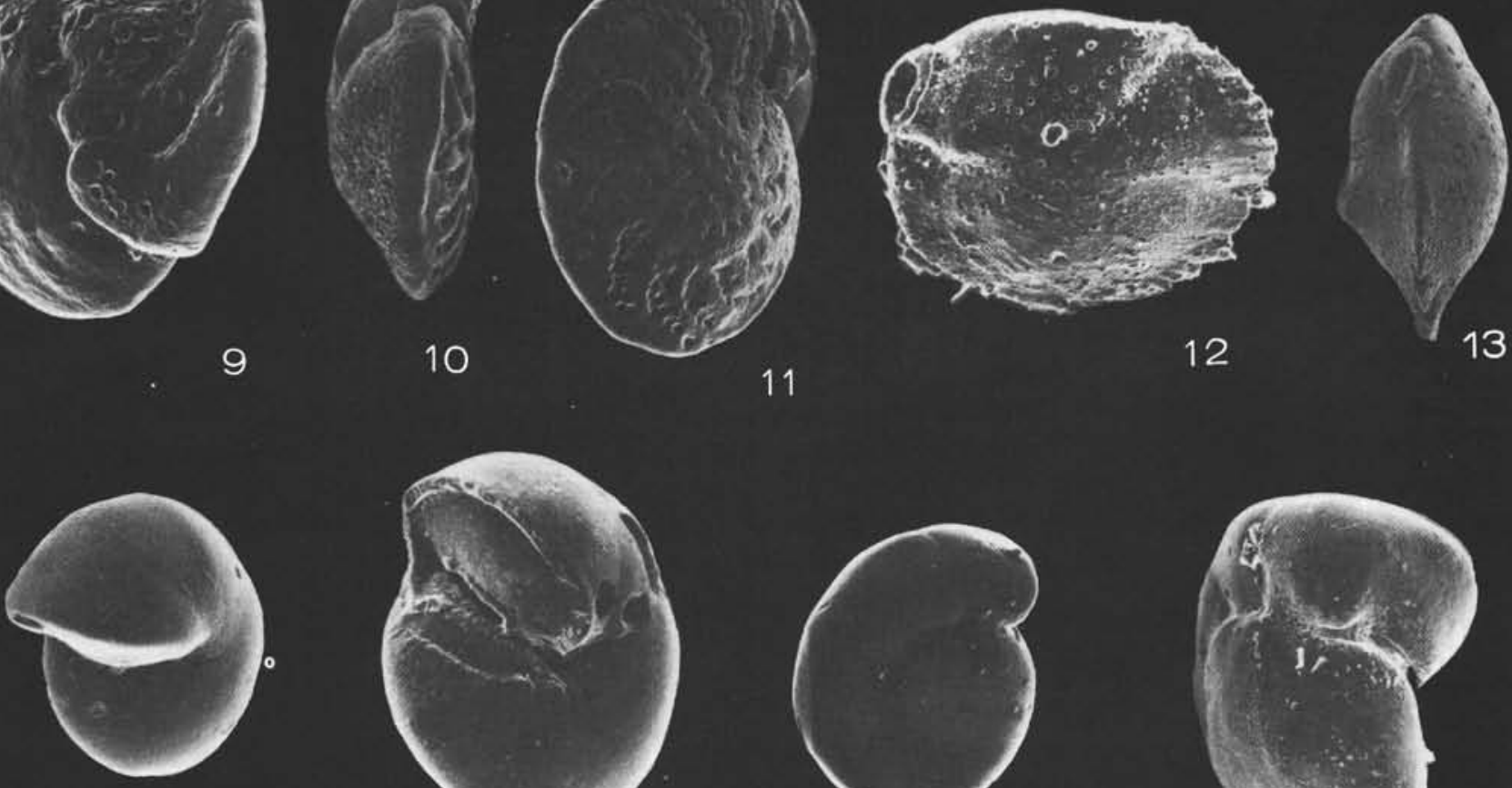

14
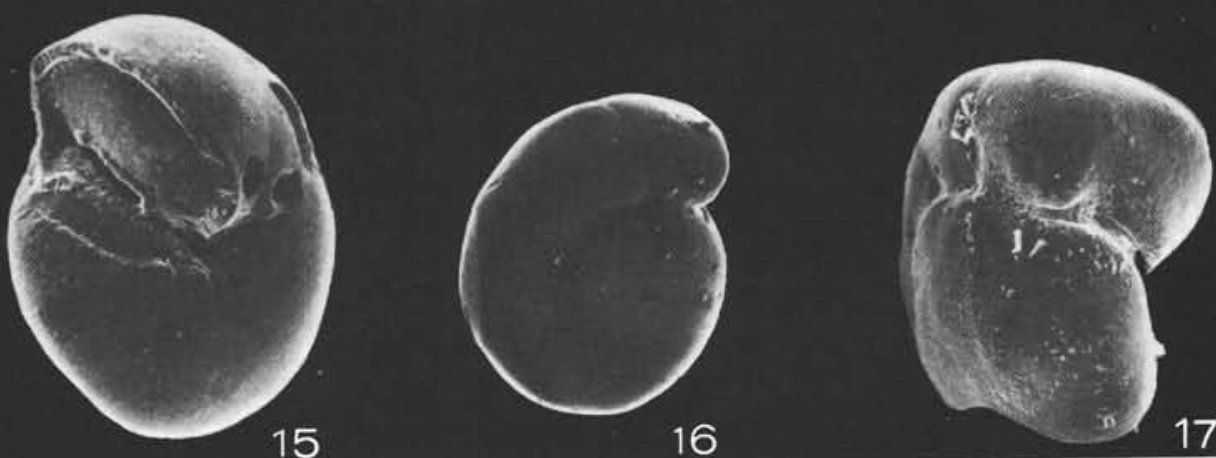
PLATE 11

All specimens are from Site 117

Figures 1,2 ?Bisaccium sp. 12-117-2, CC. 1: X134; 2: X122; Oligocene.

Figure 3 Anomalina acuta Plummer. 12-117A-8-1, 4-6 cm. X120; Late Paleocene.

Figure $4 \quad$ Planulina cocoaensis Cushman. 12-117-3, CC. $\times 100$; Oligocene.

Figures 5-8 Anomalinoides danica Brotzen. 12-117A-8-1, 4-6 cm. X120; Late Paleocene.

Figures 9-11 Cibicidoides sulzensis (Hermann). 12-117A-3-3, 142-145 cm. 9 and 10: X120; 11: X96; Early Eocene.

Figures 12,13 Cibicides sp. cf. C. praecursorius (Schwager). 12-117A-7, CC. X120; Late Paleocene.

Figures 14, 15 Cibicidoides propria (Brotzen). 12-117A-4-6, 143-146 $\mathrm{cm}$. X120; Early Eocene.

Figure 16 Gravelinella neelyi (Jennings). 12-117A-7, CC. X120; Late Paleocene.

Figures 17-20 Heterolepa mexicana (Nuttall). 12-117-2, CC. X30; Oligocene. 


\section{PLATE 11}

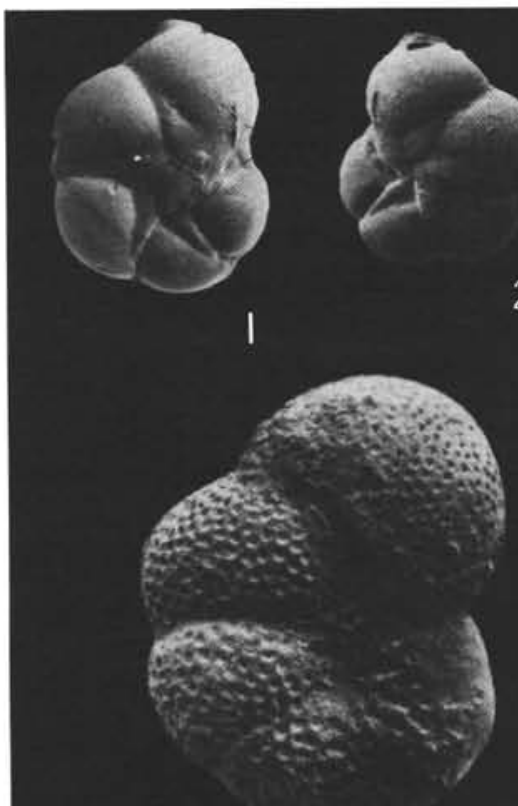

6

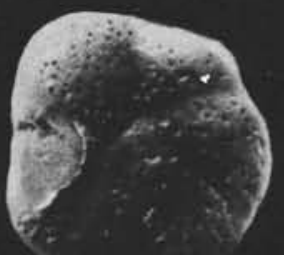

9
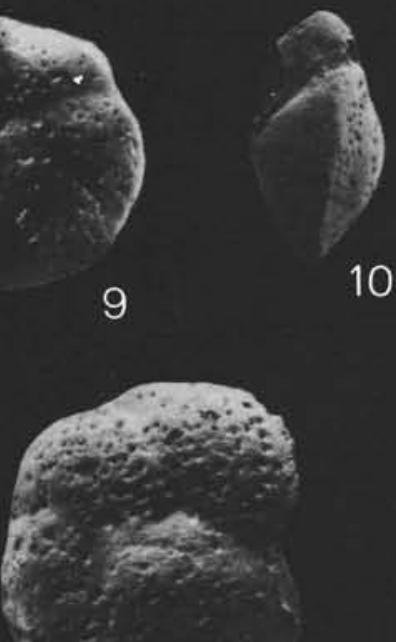

14

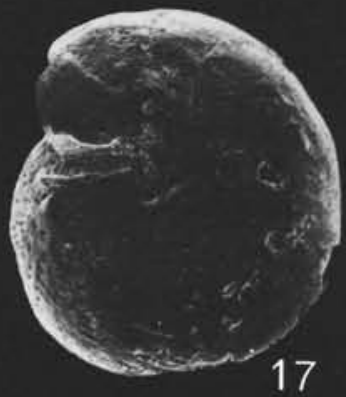

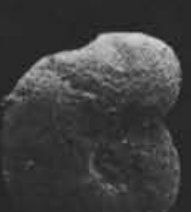

3
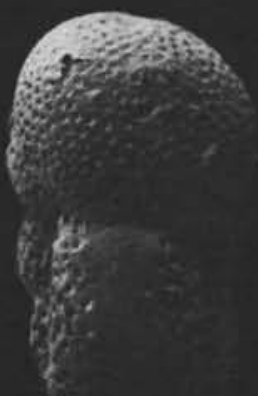

7

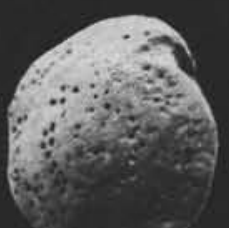

11
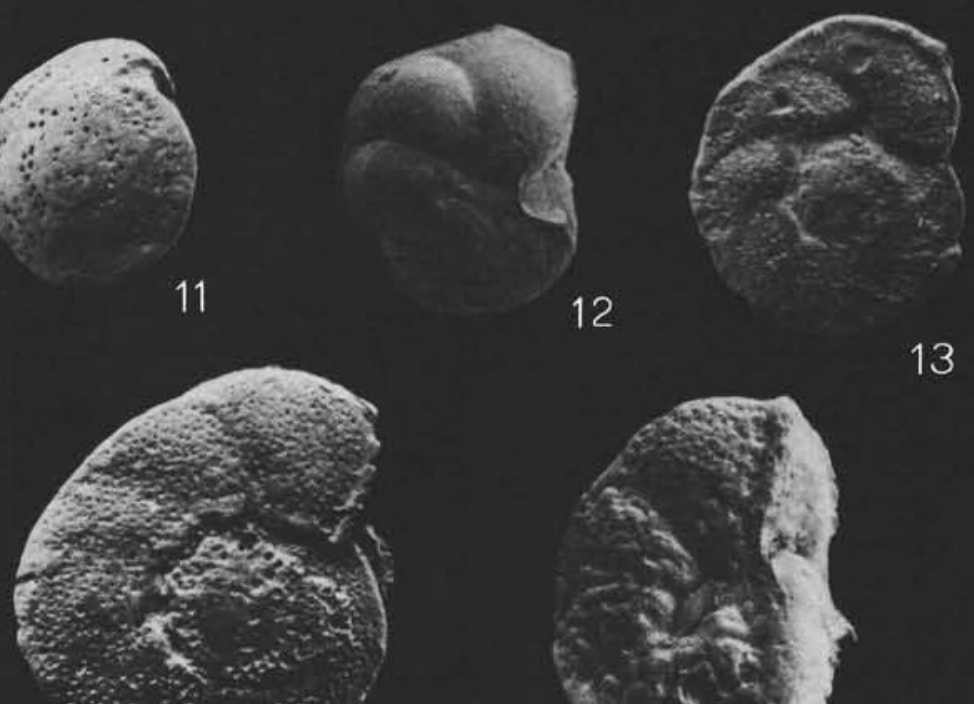

12

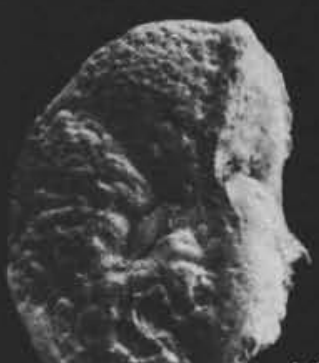

16

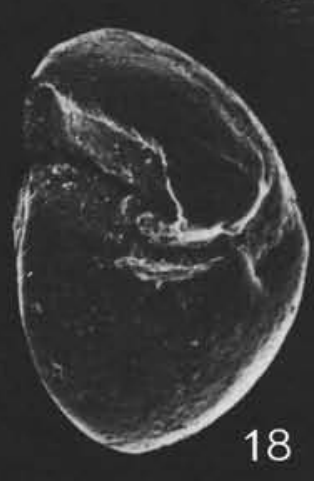

15
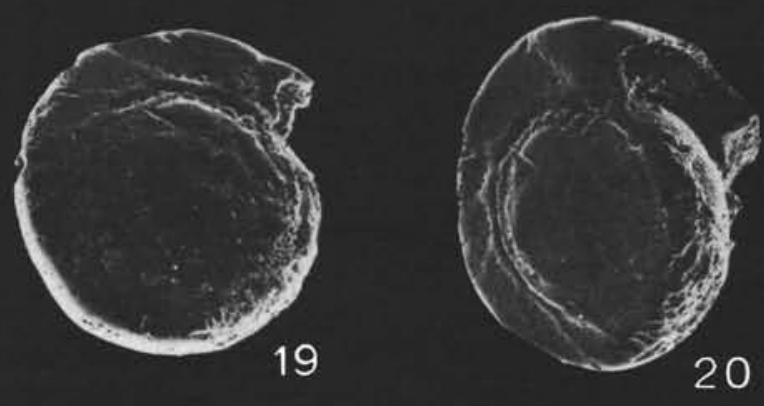
PLATE 12

All specimens are from Site 119 except Figures 1-3 (Site 118)

Figures 1-3 Nuttallides treumpyi (Nuttall). 12-118-12, CC. X132; Middle Eocene.

Figures 4, 5 Oridorsalis ecuadorensis (Galloway and Morrey). 12-119-22, CC. X132; Middle Eocene.

Figures 6-8 Alabamina dissonata (Cushman and Renz). 12-119-21, CC. 6 and $8: \times 130 ; 7: \times 260$; Middle Eocene.

Figure 9 Gyroidina planulata (Cushman and Renz). 12-119-21, CC. $\times 316$; Middle Eocene.

Figure 10 Cibicidoides cushmani (Nuttall). 12-119-22, CC. X136; Middle Eocene.

Figures 11, 12 Cibicidoides grimsdalei (Nuttall). 12-119-16, CC. $\times 60$; Oligocene.

Figures 13, 14 Cibicidoides sp. 12-119-16, CC. X25; Oligocene.

Figures 15, 16 Cibicidoides trincherasensis (Bermudez). 12-119-16, CC. X41; Oligocene.

Figures 17, 18 Anomalinoides alazanensis Nuttall. 12-119-16, CC. 17: $\times 71 ; 18: \times 64$; Oligocene.

Figures 19, 20 Vulvulina jarvisi Cushman. 12-119-21, CC. 19: X110; 20: X275; Middle Eocene.

Figure $21 \quad$ Karreriella bradyi (Cushman). 12-119-18, CC. X132; Early Oligocene.

Figure 22 Plectina cubensis Cushman and Bermudez. 12-119-21, CC. X66; Middle Eocene.

Figure 23 Buliminella grata Parker and Bermudez. 12-119-22, CC. X144; Middle Eocene. 


\section{PLATE 12}
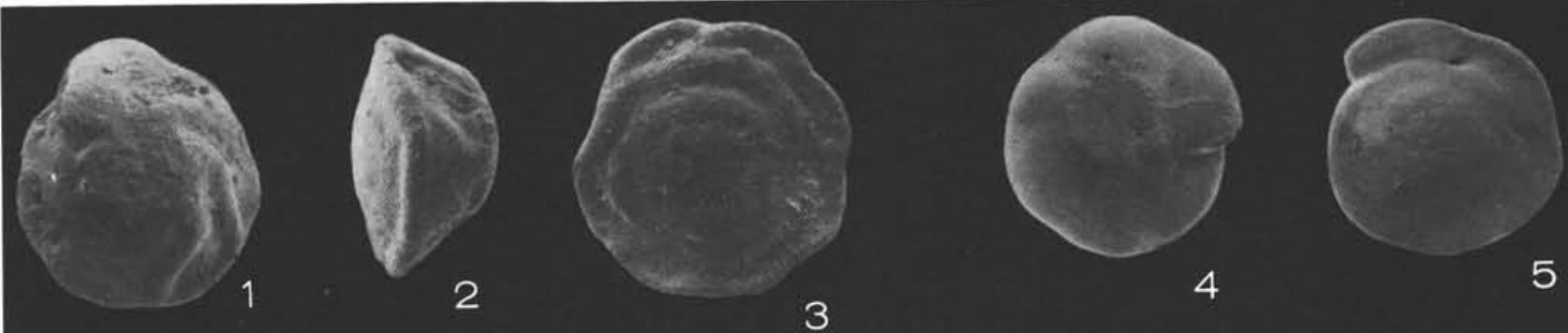

6

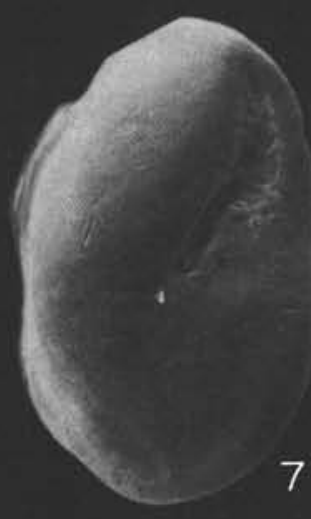

8
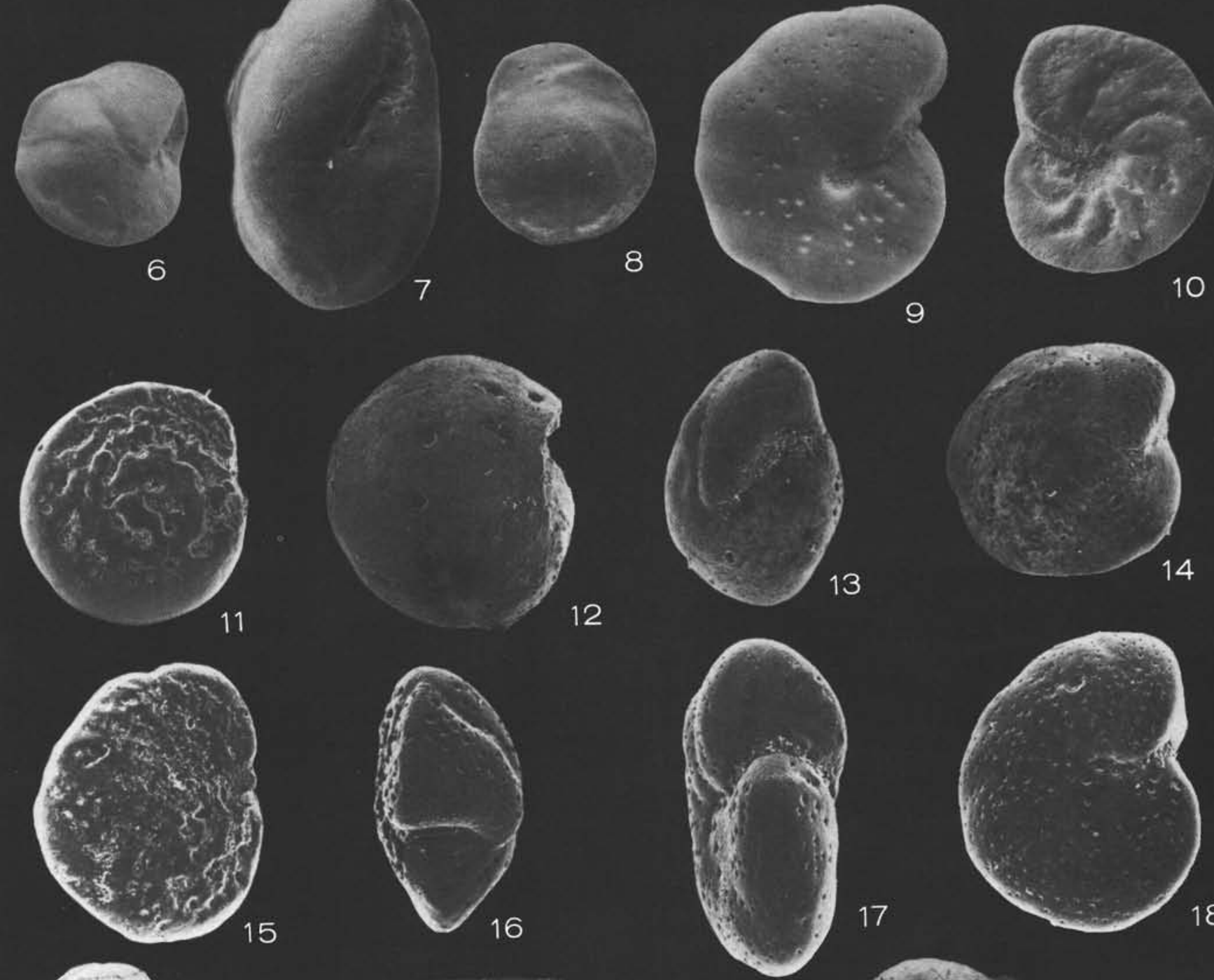

17
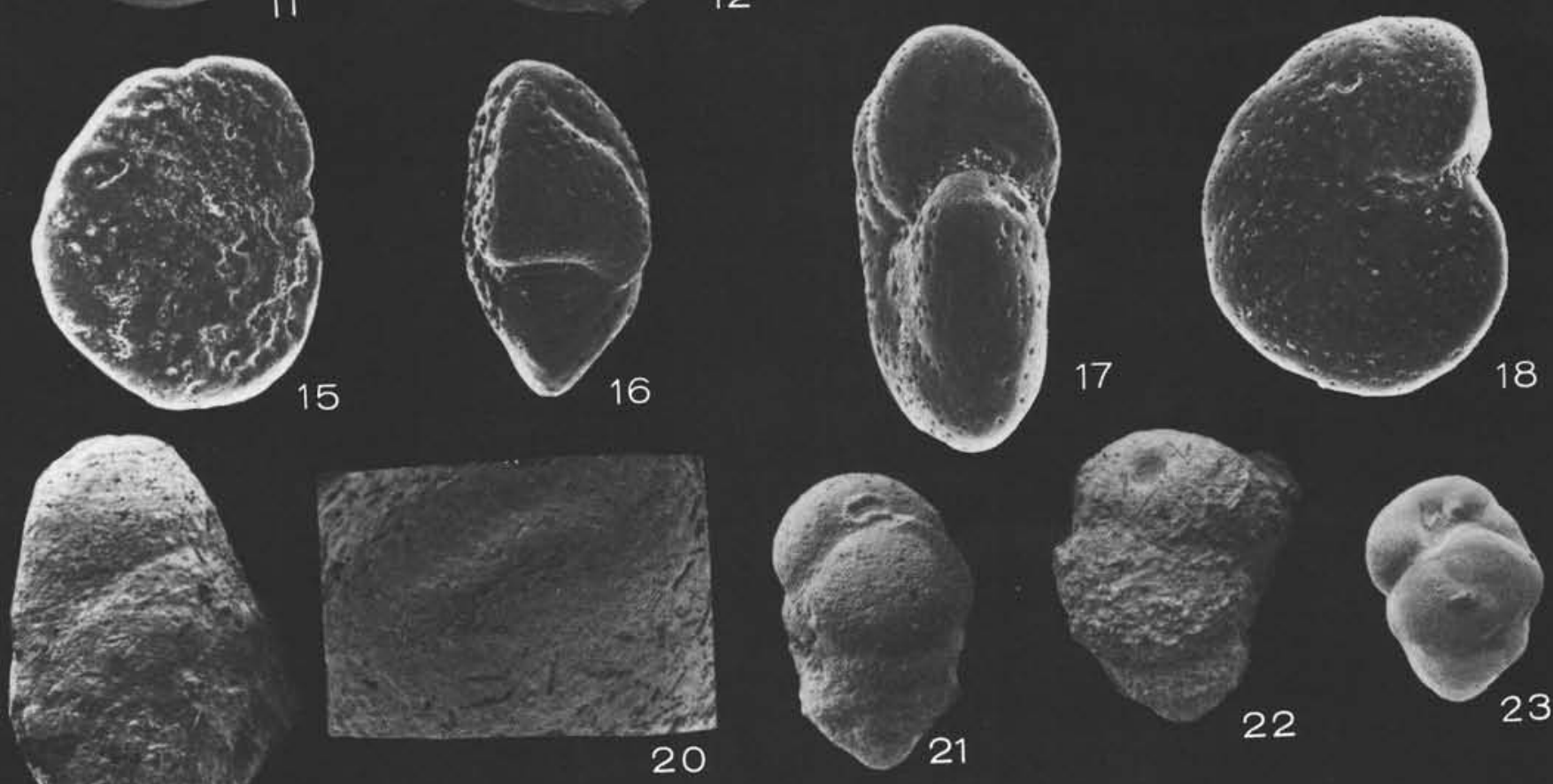


\section{PLATE 13}

All specimens are from Site 119

Figures 1, 2 Nodosarella subnodosa (Guppy). 12-119-18, CC. 1: X93; 2 : X83; Early Oligocene.

Figures 3, $4 \quad$ Stilostomella nuttalli Cushman and Jarvis. 12-119-18, CC. 3 : $\times 65 ; 4$ (apertural detail): $\times 650$; Early Oligocene.

Figure 5 Stilostomella aculeata (Cushman and Renz). 12-119-18, CC. X128; Early Oligocene.

Figure 6 Stilostomella nuttalli Cushman and Jarvis. 12-119-18, CC. X57, Early Oligocene.

Figure 7 Stilostomella gracillima (Cushman and Jarvis). 12-119-21, CC. X60; Middle Eocene.

Figures 8,9 Nodosarella mappa (Cushman and Jarvis). 12-119-21, CC. 8 (apertural detail): $\times 260$; 9: $\times 130$; Middle Eocene.

Figure 10 Cibicidoides grimsdalei (Nuttall). 12-119-18, CC. X136; Early Oligocene.

Figures 11-13 Anomalina spissformis Cushman and Stainforth. 12-119-18, CC. X133; Early Oligocene.

Figures 14-16 Cibicidoides trinitatensis Beckmann (non Nuttall). 12-119-21, CC. 14 and 15: X130; 16: X116; Middle Eocene.

Figures 17-19 Cibicidoides martinizensis (Cushman and Barksdale). 12-119-21, CC. X130; Middle Eocene. 


\section{PLATE 13}

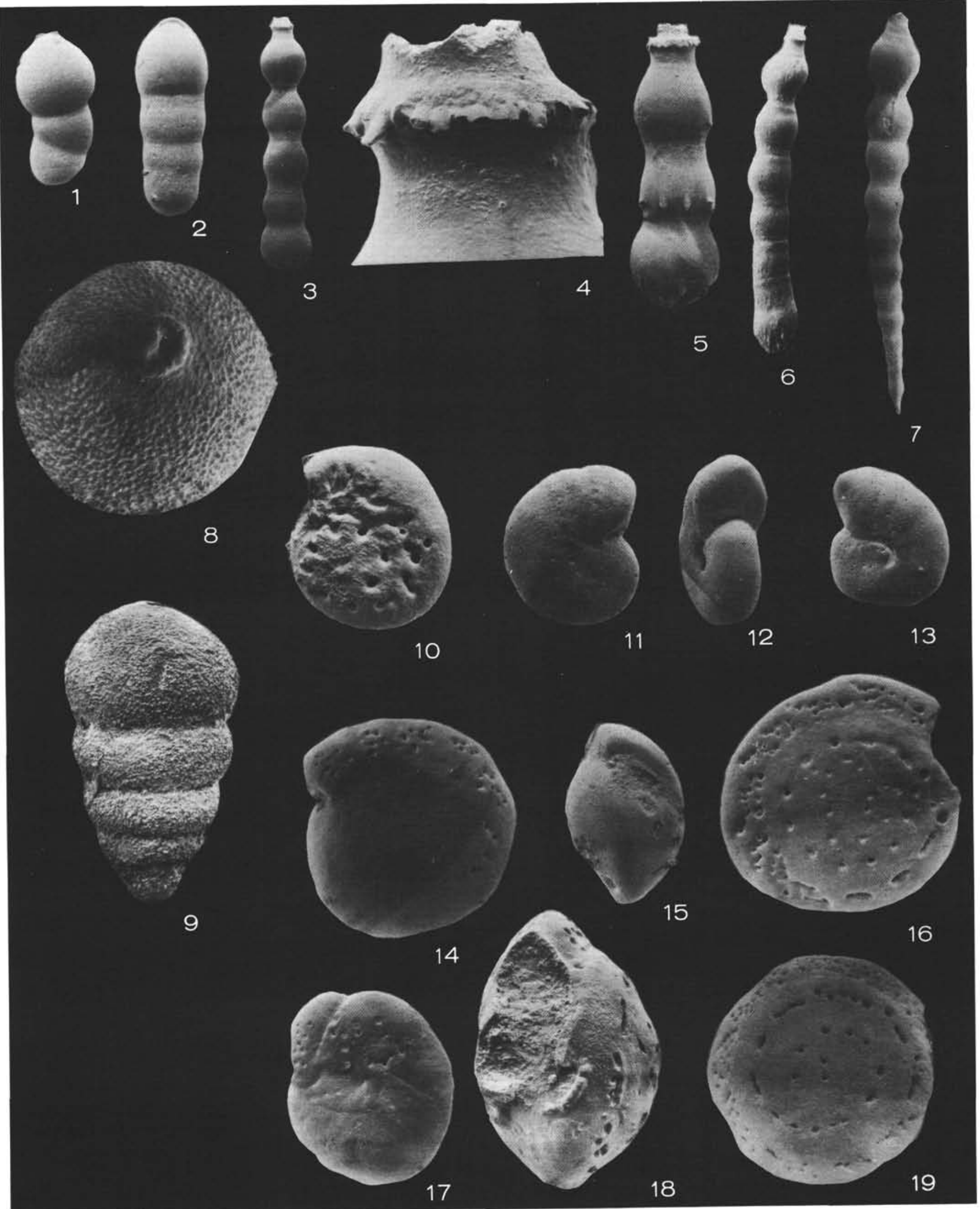

